\title{
Review of the Current State of UAV Regulations
}

\author{
Claudia Stöcker ${ }^{1, *}$, Rohan Bennett ${ }^{1,2}$, Francesco Nex ${ }^{1}$, Markus Gerke ${ }^{3}$ and Jaap Zevenbergen ${ }^{1}$ \\ 1 Faculty of Geo-Information Science and Earth Observation ITC, University of Twente, \\ Hengelosestraat 99, 7514 AE Enschede, The Netherlands; rohanbennett@swin.edu.au (R.B.); \\ f.nex@utwente.nl (F.N.); j.a.zevenbergen@utwente.nl (J.Z.) \\ 2 Faculty of Business and Law, Swinburne University of Technology, P.O. Box 218, \\ Hawthorn VIC 3122, Australia \\ 3 Institute of Geodesy and Photogrammetry, University of Baunschweig, \\ Pockelsstraße 14, 38106 Braunschweig, Germany; m.gerke@tu-bs.de \\ * Correspondence: e.c.stocker@utwente.nl; Tel.: +31-53-4894099
}

Academic Editors: Guoqing Zhou and Prasad S. Thenkabail

Received: 17 February 2017; Accepted: 4 May 2017; Published: 9 May 2017

\begin{abstract}
UAVs - unmanned aerial vehicles-facilitate data acquisition at temporal and spatial scales that still remain unachievable for traditional remote sensing platforms. However, current legal frameworks that regulate UAVs present significant barriers to research and development. To highlight the importance, impact, and diversity of UAV regulations, this paper provides an exploratory investigation of UAV regulations on the global scale. For this, the methodological approach consists of a research synthesis of UAV regulations, including a thorough literature review and a comparative analysis of national regulatory frameworks. Similarities and contrasting elements in the various national UAV regulations are explored including their statuses from the perspectives of past, present, and future trends. Since the early 2000s, countries have gradually established national legal frameworks. Although all UAV regulations have one common goal-minimizing the risks to other airspace users and to both people and property on the ground-the results reveal distinct variations in all the compared variables. Furthermore, besides the clear presence of legal frameworks, market forces such as industry design standards and reliable information about UAVs as public goods are expected to shape future developments.
\end{abstract}

Keywords: UAV; unmanned aerial vehicle; RPAS; regulation; comparative analysis; law and technology

\section{Introduction}

UAVs - unmanned aerial vehicles-are aircraft which are intended to operate without a pilot on board [1]. Although UAVs have their origins in military contexts, they have also become valuable for scientific and commercial applications, particularly over the previous decade [2,3]. Various stakeholders and actors, including governmental authorities, commercial operators, scientific institutions and individuals, make use of UAVs as an affordable data acquisition tool: they enable mapping at temporal and spatial scales that still remain unachievable for traditional remote sensing platforms [3-6]. The range of distinct applications spreads through various civil applications, including high-resolution surface reconstruction in the geosciences [7-10], documentation of cultural heritage and archaeological sites [11], agriculture and forest change detection [12-16], support for disaster management [17-19], surveying and mapping [20-25], land administration [26-29] and wildlife observation [30,31]. In this context, Pajares [32] delivers a detailed review of the broad spectrum of UAV-based remote sensing applications.

Compared to satellite-based operations or traditional manned photogrammetric surveys, UAV flight missions provide high operational flexibility in terms of costs, place, platforms, time and repeatability [3,33-35]. For these reasons, UAVs are seen as highly complementary to traditional remote 
sensing platforms, and as having the potential to replace certain measurements that are conventionally acquired by satellites, manned aircraft, or by means of direct ground-based surveying. Considering the economic and functional benefits, a steadily growing market for both commercial manufacturers and civil applications of UAV is reported $[4,36]$.

However, recent technological improvements and increasing operational capabilities present certain challenges to flight operators, end users and aviation authorities: especially concerns about privacy, data protection, and public safety [37]. To minimize the risks of UAV-triggered incidents or accidents, an increasing number of national and international authorities have introduced legal provisions that mandate "Go," "No go" or "How to go" statements that either allow, prohibit or restrict flight operations. Such regulations significantly impact how, where, and when data can be captured-and the diffusion of the technology within a national context.

Due to the rapid emergence of this technology, UAV regulations are still embryonic and a heterogeneity of national rules and varying levels of implementation can be observed [6,38]. The CEO of the AscTec UAV company stresses that "legislation and policymaking is lagging way behind the technology" [39]. This lack creates a significant barrier to research and development as scientific projects are hindered [6], as are both private and public innovation. As a result, market opportunities and societal gains are not being exploited [40]. Common problems with UAV regulations include flight approval times [41] and poorly documented administrative processes that limit the desired flexibility and impede the widespread utilization of the technology. However, some national aviation authorities and international organizations are already moving to "modernize" the first wave of regulations: they seek to accommodate user demands and recent technological developments while still aiming to maintain safe operations.

Motivated by a lack of a sound overview of the recent developments of UAV regulations, this review article highlights the importance of UAV regulations as one prerequisite that dictates when, where, under which conditions and by whom data can be captured. Furthermore, it will help to better understand the impact of UAV regulations for the remote sensing community as this review unveils practical limitations of UAVs as a remote sensing platform and the need for improved technical solutions. The goal of this paper is therefore to provide an exploratory investigation of UAV regulations on the global scale. This includes a global overview and a thorough discussion of main criteria that are mandated in the regulations. Next, we particularly highlight time as an additional dimension in order to distinguish past, present and expected future developments.

To this end, and to underline the urgency of the work, the following section presents the background to contemporary socio-technical perspectives on UAV regulations. Materials and methods, including the data utilized and analysis techniques applied, are then outlined. The results section present the status of UAV regulations from the perspective of past, present, and future trends. Similarities and contrasting elements in various national UAV regulations and their implications for data acquisition activities are explored. In addition, the work investigates and discusses current considerations of privacy, data protection and public safety within the legal frameworks for operating UAVs. In considering the scientific discourse on "law and technology" and the current state of UAV regulations, possible future trends are outlined. The discussion section aims to place the results into the context of the state-of-the-art and to show the limitations of the data utilized in the work and of the applied methods. Finally, conclusions are drawn and directions for future work suggested.

\section{State of the Art}

Before the section proceeds with important background information, it is necessary to spend a few lines on the definition of UAVs. Although UAV is the most well-known term in both professional and non-professional domains, regulatory bodies like the International Civil Aviation Authority (ICAO) emphasize clear distinctions between UAVs — these are of particular interest for the applicability of laws and regulations. According to [42], the broad group of UAVs can be distinguished to remotely piloted aircrafts (RPA) and autonomous aircrafts. Here, the latter refers to UAVs that do not allow 
pilot interventions during the flight and are mainly used in military contexts. The former one refers to unmanned aircrafts which are remotely controlled by a pilot [42]. RPA are mainly used for civil applications. Model aircrafts represent a third group and are defined to be solely intended for fun and recreational purposes. As the ICAO nomenclature is not yet implemented in all countries, different use of this terminology was observed. However, the following sections only acknowledge regulations, statements and content that focus on civil applications.

UAV regulations have already been mentioned in various publications-a refined Scopus literature search found more than 300 publications (conference paper, articles, reviews ... ) from the year 2000 onwards. However, authors of relevant articles either discuss the topic from the perspective of one context (e.g., privacy), technical specification (e.g., sense and avoid systems) or cover only a few countries.

Although the legal provisions are one important part of the preparation phase of UAV data acquisition flights, most technically or application-oriented articles do not specifically mention the regulations that were applicable to their data collection flights [6]. Some review articles on UAV applications discuss UAV legislative frameworks: they present national and international regulatory bodies and give short introductions to risk-based approaches, UAV safety level classifications and current efforts of international organisations to harmonize UAV legislation [3,4,13]). However, the works provide only brief overviews and remain highly generalized. In this context, the regulations of the Federal Aviation Administration (FAA-US) are exceptional and need to be emphasized in particular as they are subject to dedicated research articles [6,41]. Rango and Laliberte [41] stress the impact of regulations for UAV operations in the US and highlight safety procedures that need to be followed. They further indicate a desired future situation that mainly concerns beyond visual line-of-sight (BVLOS) flights and simplified administration procedures. In a comparison of six different national regulations, Morales et al. [43] evaluated different options for Colombian regulations.

In contrast to technically or application-oriented articles, scientific publications with social-technical background are mainly focussed on societal aspects. Here, the discourse of UAV regulations includes public safety and liability in case of an accident, societal benefits and stakeholders in international regulatory bodies such as the European Commission [40], rule-guided risks and opportunities of UAV [44], ethical tolerability [45], and effects upon privacy and other civil liberties [46]. The latter mentioned authors further used self-reported material of representatives of different drone sectors (including civil aviation authorities and data protection authorities) to study perspectives on privacy, data protection and ethical aspects [47]. They detected "[ ... ] significant gaps in the industry's knowledge about their privacy, data protection and ethical obligations under European and national laws" and that the legislation regarding these concerns lacks tremendously [47]. Interestingly, Boucher [40] showed another example of non-compliance. The authors conclude that the strategies to manage public acceptance in the European roadmap [48]) do not conform with the European concept of responsible research and innovation [49]. Furthermore, in a series of four scientific papers, R. Clarke identified risks and drawbacks of the utilization of UAV. Among others, he particularly raises the topic of air safety laws and summarizes national as well as international legislation as incomplete due to "[ ... ] inadequate and very slowly-adaptive formal regulation" [50].

The literature review reveals that although the methodologies of application-oriented articles differ from those with socio-technical backgrounds, the subject of interest is in many cases the same-e.g., FAA regulations. However, very few cross-citations from one domain to the other were noted.

Currently, lobby groups including UVS International are pushing towards regulatory standards and harmonization. International roadmaps as in Europe [48] anticipate a bright future with full integration of civil UAV into national aviation systems. In contrast to these prospects, lawyers and social scientists emphasize privacy, data protection and public safety concerns and identify major gaps in current regulatory frameworks. At the same time, emerging and fast developing technologies such as UAV often involve legal problems [51] due to inflexibility and slow adaptation processes of 
formal laws. The different evidence, perspectives, and visions of scholars and various stakeholders alike-let alone (sometimes inappropriate) media reports-make it hard to draw a clear picture of past developments, current status and future trends of UAV regulations. Thus far-to the best of the authors' knowledge-no scientific publication comprehensively undertakes an analysis of different statuses of UAV regulations. In response, this article seeks to develop a holistic perspective by synthesizing approaches, concepts and ideals gained from a comprehensive analysis of civil UAV regulatory frameworks and recent scientific literature from the fields of law, innovation, and technology.

\section{Data Sources and Methods}

The overall methodology encompasses a research synthesis of multiple data sources that are related to UAV governance, legislation, and regulatory frameworks. In general, a research synthesis uses existing facts and multiple sources to make generalizations about the topic of research [52] and thus fits the aim of providing a comprehensive overview of UAV regulations and their implications for flight operations. The first methodological pillar of the research synthesis is a comparative analysis of the various documents that regulate UAV operations. This analysis embraces national regulatory frameworks, international principles and guidelines, which are analysed in a comparative manner. Facilitated by a range of variables, a point-by-point comparison allows for both quantitative and qualitative analysis. The variables are assigned to a set of six criteria that consider the main aspects of UAV regulations. Criteria and respective variables were derived following a heuristic approach based on an iterative review process of legal frameworks for the use of UAVs. Hence, the findings provide an overview of the characteristics of both past and present UAV regulatory approaches and enable predictions of future trends. In addition, a review of the scientific literature that focusses on the relationship between law, innovation, and technology constitutes the second pillar of the methods for this research synthesis. The literature is reviewed from the point of view of legal considerations of UAV regulations and lessons learned from other "problems with 'technology' as a regulatory target" [53]. Outcomes will provide further inputs for the prediction of possible future trends. The framework for this analysis is outlined in Figure 1.

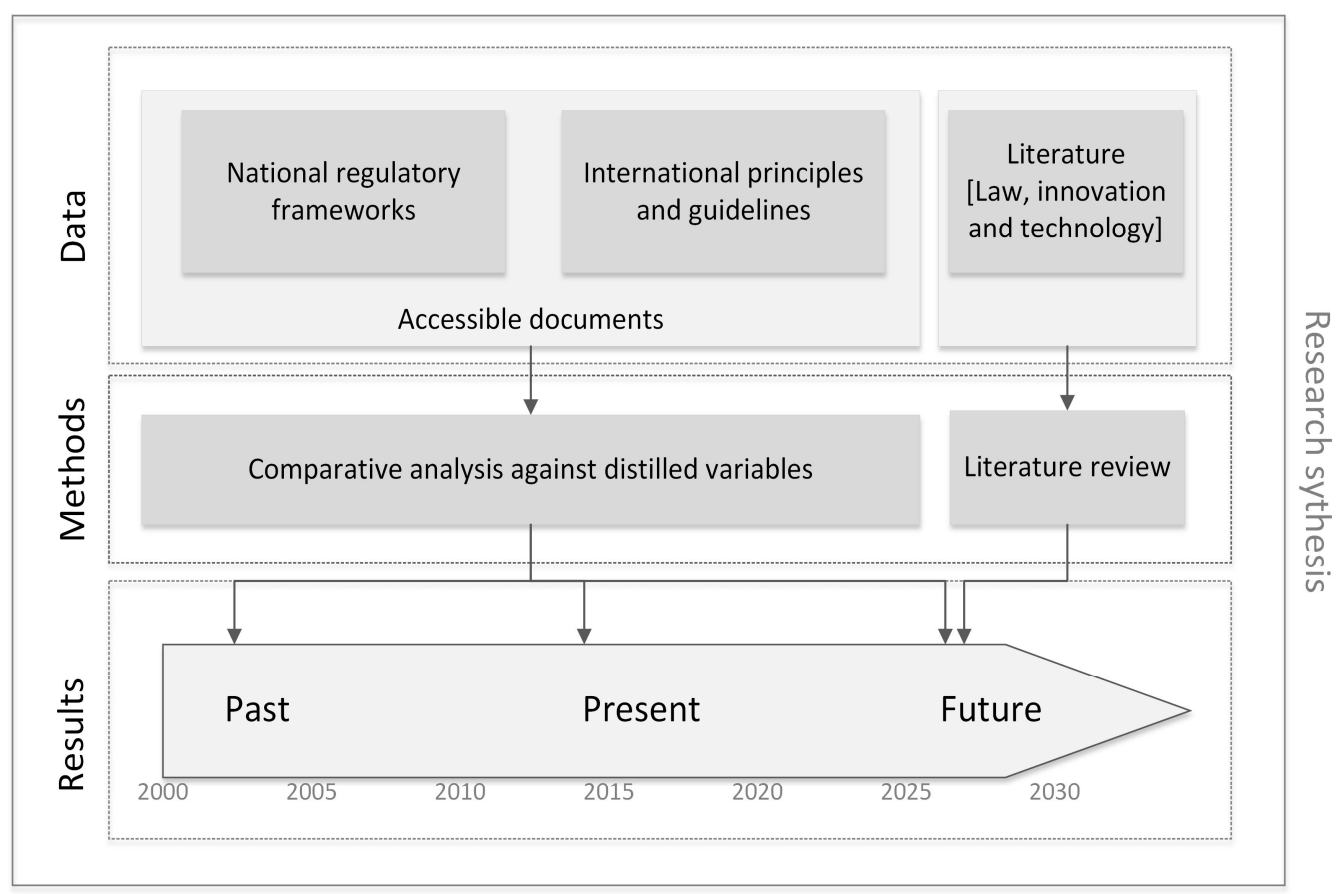

Figure 1. Schematic overview of research framework and process flows-including data, analysis and results. 


\subsection{Database}

To ensure an objective and reproducible database, the search strategy and selection criteria need to be explicitly outlined. The first step of the search strategy targets national UAV regulations and involves a comprehensive online-search. Due to local language constraints, an online-search of regulatory documents country by country would be impractical for this project. Thus, internet sources of relevant international UAV organizations are reviewed for precompiled lists and overviews. Table 1 presents a list of known sources that provide links to national UAV regulations and briefly outlines their content. Please note that this online search was conducted in October 2016 and therefore does not consider later publications.

Table 1. Overview of online accessible lists and overviews of unmanned aerial vehicle (UAV) regulations (status October 2016).

\begin{tabular}{|c|c|}
\hline Internet Presence & Content \\
\hline $\begin{array}{l}\text { http:/ / www.eurocontrol.int/articles / national-rpas- } \\
\text { regulations [54] }\end{array}$ & $\begin{array}{l}\text { EUROCONTROL: List } 23 \text { different national UAV regulations } \\
\text { and provide links to respective documents. }\end{array}$ \\
\hline http://jarus-rpas.org/regulations [55] & $\begin{array}{l}\text { Joint Authorities for Regulation of Unmanned Systems } \\
\text { (JARUS): List } 24 \text { different national UAV regulations and } \\
\text { provide a comparison of } 26 \text { countries. }\end{array}$ \\
\hline https://droneregulations.info/index.html [56] & Collaborative wiki: Global UAV Regulations Database. \\
\hline $\begin{array}{l}\text { http:/ / uvs-info.com/index.php/european-matters / } \\
\text { regulation-monitor-europe/european-matters- } \\
\text { regulation-monitor-europe-open-access [57] }\end{array}$ & $\begin{array}{l}\text { UVS International: Regulation monitor for UAV regulations in } \\
\text { Europe (status: } 17 \text { March 2014), access to other documents is } \\
\text { restricted and necessitates user registration. }\end{array}$ \\
\hline http://dronerules.eu/en/ [58] & $\begin{array}{l}\text { Homepage is co-funded by the European Union: } \\
\text { The organizers aim for an online interface for national } \\
\text { regulatory profiles in EU member states and Norway and } \\
\text { Switzerland (planned for January 2017). }\end{array}$ \\
\hline
\end{tabular}

Due to the rapid emergence of and ongoing changes to UAV regulations, none of the collections provides a reliable, complete and coherent picture of the worldwide situation. Links, documents and information are either outdated, incomplete or still in development and therefore not yet released. Thus, this article used all links available from these platforms for a global overview of UAV regulations. Based on this information, a sub-sampling of regulations for a deep and detailed comparative analysis was realised. Consequently, the representative sample of a total of 19 regulations aims to cover all continents-and a diverse range of legal systems, economic development levels, and geographical environments. Furthermore, various times of first release were acknowledged in order to identify both pioneers and followers.

Documents with an international context set out various principles, guidelines, codes of conduct and roadmaps. Oral communications and references from the grey literature provided an additional valuable source of information.

\subsection{Methods}

A comparative analysis is a very general research method [59]: it compares two or more cases and thus puts a particular sample of cases into a relation. The rationale behind a comparative analysis in the context of UAV regulations is to aim for a narrative of developments, commonalities, and differences in various regulatory documents. To achieve a quantitative point-by-point analysis, rather than a qualitative case-by-case comparison [60], measurable variables need to be determined. Twenty variables were distilled in a heuristic approach by an iterative review and comparison of UAV regulations. In our case, all variables are dichotomous [61] and can show one of two characteristics: addressed or not addressed by respective UAV regulations. In addition to this, the analysis includes descriptive information of the majority of variables in order to improve their significance and to highlight the qualitative variations among certain characteristics. 
As shown in Table 2, six main criteria and respective variables were chosen. (1) Applicability refers to the scope of respective regulations. In this group, the first two variables distinguish the applicability of regulations to model aircraft (MA) or UAVs. Furthermore, applicable classifications and weight limits are addressed by the latter two variables. (2) Technical prerequisites acknowledge essential instruments that are mandated. Referring to current technological developments, collision avoidance capabilities are treated as an individual variable. (3) Operational limitations cover restrictions for the flight itself and include the following variables: distances to airports/airstrips and to people, limitations to operating over congested areas, acknowledgement of prohibited areas, additional limitations, maximum flying height, and limitations regarding the visibility of the UAV. (4) Administrative procedures refer to visits to authorities as well as required documents and services. In this context, the application procedure, the need for registration and the required level of insurance cover are separate variables. (5) Human resource requirements encompass the piloting skills mandated. (6) Implementation of ethical constraints refers to the inclusion of or references to respective privacy and data protection regulations.

Table 2. Overview of criteria and variables of the comparative analysis.

\begin{tabular}{|c|c|}
\hline Criteria & Variable(s) \\
\hline Applicability & $\begin{array}{l}\text { Applicable for model aircrafts (MA), applicable for UAVs, classification, } \\
\text { weight limits }\end{array}$ \\
\hline Technical requirements & Required instruments, required level of sense and avoid mechanism \\
\hline Operational limitations & $\begin{array}{l}\text { Distance to airports/strips, limitations to fly over people, limitations over } \\
\text { congested areas, prohibited areas, additional limitations, maximal flying } \\
\text { height, visual line-of-sight, beyond visual line-of-sight }\end{array}$ \\
\hline Administrative procedures & $\begin{array}{l}\text { Application procedure and operational certificate, need for registration, } \\
\text { need for insurance }\end{array}$ \\
\hline Human resource requirements & Qualification of pilots \\
\hline Implementation of ethical constraints & $\begin{array}{l}\text { Indication of requirements for data protection, Indication of requirements } \\
\text { for privacy }\end{array}$ \\
\hline
\end{tabular}

This comparison builds the base of the discourse regarding pioneering countries and the identification of possible trends. The outcomes will be reflected towards current mandates of international organizations and lobby groups.

\section{Analysis}

As UAVs are a new object in the airspace they pose a potential risk to other airspace users as well as to third parties on the ground. Therefore, a growing number of countries are establishing regulations in order to minimize this risk. The results reveal that UAV regulations are subject to national legislation and focus upon three key aspects: (1) targeting the regulated use of airspace by UAVs as they pose a serious danger for manned aircrafts; (2) setting operational limitations in order to assure appropriate flights; and (3) tackling administrative procedures of flight permissions, pilot licenses and data collection authorization.

As presented in Figure 2, the global overview of UAV regulations as per October 2016 reveals that nearly one-third of all countries have respective regulatory documents in place. Approximately half of all countries do not provide any information regarding the use of UAVs for civil applications. However, this does not imply that flights are per se prohibited or allowed. Announcements for pending UAV regulations were found in 15 countries. On this, some countries (e.g., Kenya) already published draft versions and the official legal framework is expected in 2017. In Cuba, Egypt and Uzbekistan, UAVs are officially banned which prohibits the use of this platform. In 13 cases, the information of relevant precompiled lists could not be validated and no documents were found that prove the existence of particular regulations. 
The next subsections briefly cover past developments and highlight present states of application both in national and international contexts. Identified trends and challenges for the future are part of the discussion.

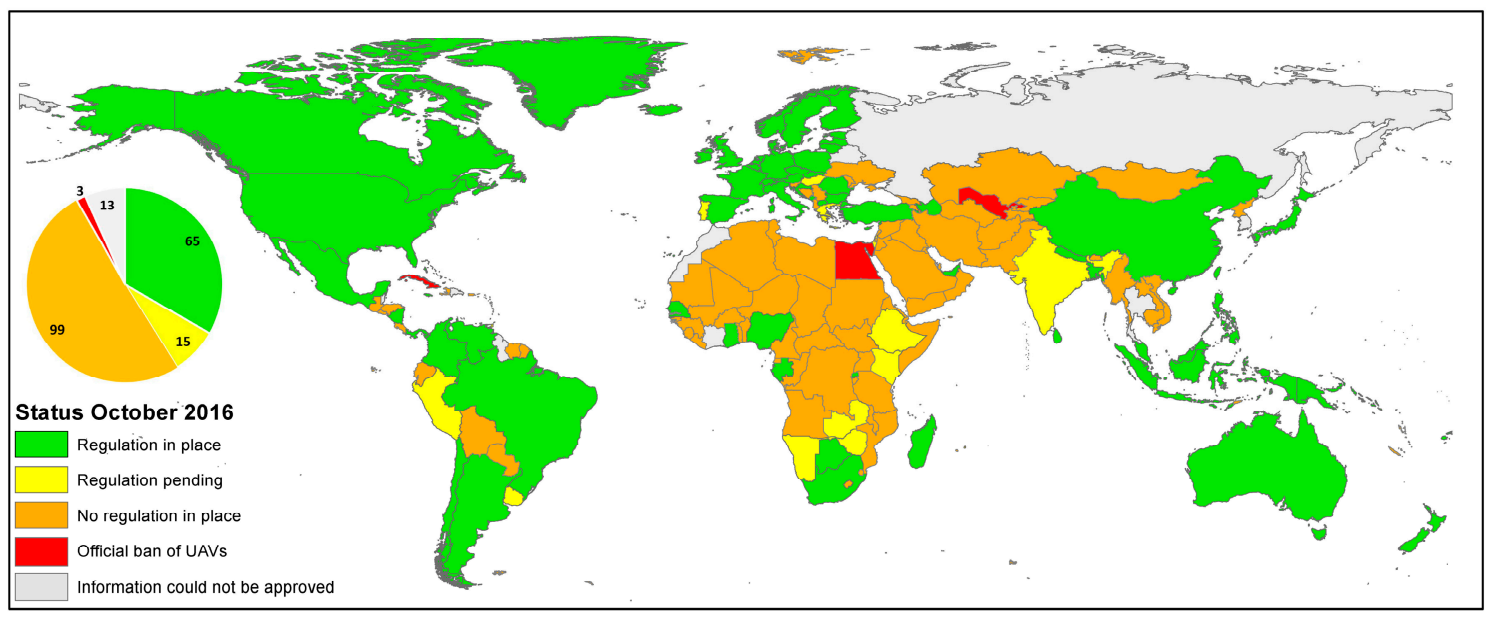

Figure 2. Global overview of current status of unmanned aerial vehicle (UAV) regulations on a country-level resolution (status: October 2016).

\subsection{Past}

The history of UAV regulations dates back to manned aviation and the emergence of airplanes during World War II. In 1944, the international community established the first globally acknowledged aviation principles-the Chicago Convention. Besides the main focus on requirements for safe and secure flights in manned aviation, one article addresses pilotless aircrafts and highlights the need for special authorization of UAV operations.

"No aircraft capable of being flown without a pilot shall be flown without a pilot over the territory of a contracting State without special authorization by that State and in accordance with the terms of such authorization. Each contracting State undertakes to ensure that the flight of such aircraft without a pilot in regions open to civil aircraft shall be controlled as to obviate danger to civil aircraft."-Article 8 [62].

Due to the early developments of UAVs in the form of manipulated model aircrafts [5], UAV operations were usually conducted under respective regulations for model aircrafts [41]. In the 2000s-after years of technological research and innovation-UAVs developed into a commercially workable system. Hence, in 2006, the ICAO identified and declared the need for international harmonized terms and principles of the civil use of UAVs [42]. At this time, five countries had already established and enacted UAV regulations (see Figures 3 and 4). UK and Australia were the first nations that promulgated regulations in 2002. Several countries followed; however, even by 2012 the propagation of national UAV regulations remained very limited. From 2012 onwards, this trend changed and an increasing number of countries established national UAV regulations: between 2012 and $2015 / 2016$ more than $80 \%$ of the 65 countries with national regulations enacted them.

Generally speaking, national UAV regulations were established in reaction to the growing UAV industry and the identified need to regulate the emerging technology for public safety. In several cases, countries further promulgated regulations as a response to high-profile incidents, as witnessed in Japan. Here, UAVs were originally widely operated without a sophisticated regulatory framework. However, an incident where a UAV that carried radioactive soils and intentionally landed on the rooftop of the Prime Minister's office triggered the discussion and the subsequent revision and amendment of the Japanese Aviation Act [63]. 


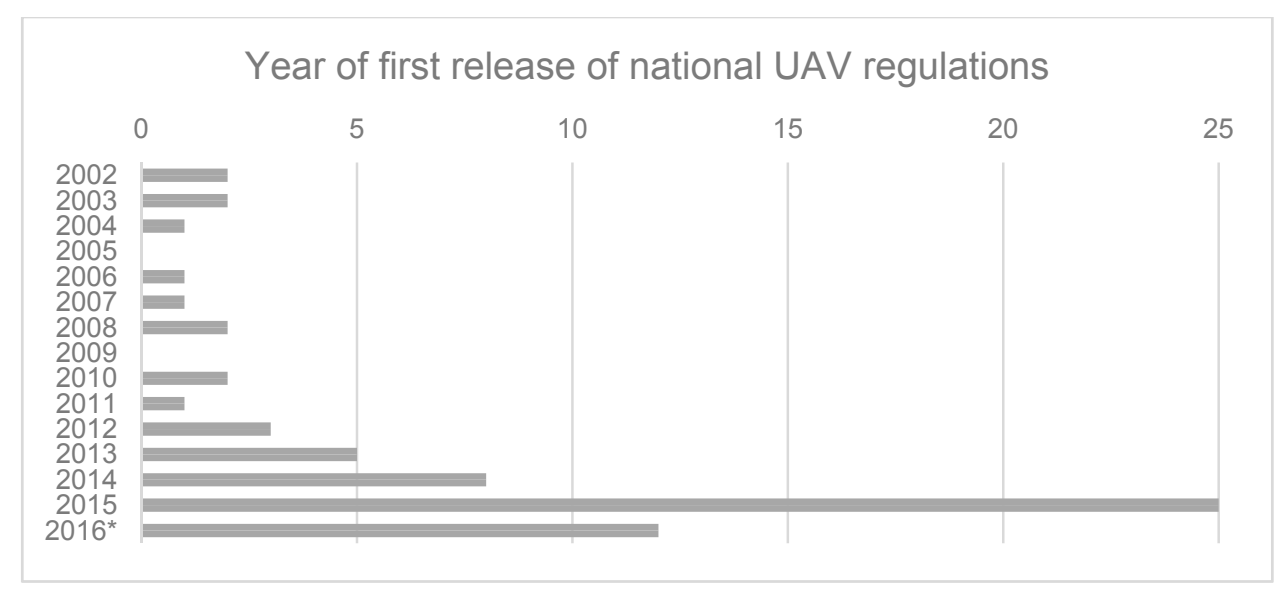

Figure 3. Temporal overview of first releases of UAV regulations on country level resolution ${ }^{*}$ status: October 2016).

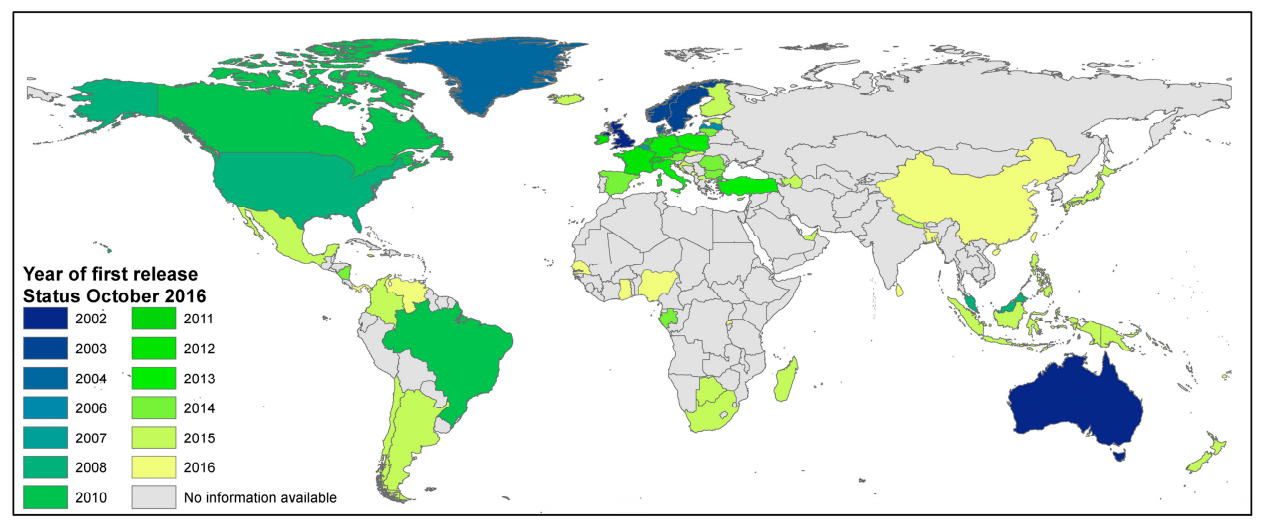

Figure 4. Global distribution of first releases of UAV regulations on country level resolution (status: October 2016).

Besides national efforts to introduce UAV regulations, international organizations took initiatives in parallel. In 2002, the Joint Aviation Authorities (JAA) and European Organization for the Safety of Air Navigation (EUROCONTROL) jointly established a UAV Task Force aimed at safely integrating UAVs into European Airspace through the setting out of a guiding concept for civil UAV regulations [64]. As a successor of the JAA, the European Safety Aviation Authority (EASA) further pursued this mission from 2008 onwards. Various documents for the development of one European policy on UAVs were published. In 2012, the European Commission set up the European RPAS steering group (ERSG) - a gathering of organizations and experts in this field. ERSG received the mandate to create a roadmap for integration of civil UAVs into the European aviation system [48].

Next to the regional context of Europe, global interest groups and professional organizations such as the Joint Authorities for Rulemaking on Unmanned Systems (JARUS) — a special UAV study group of ICAO-evolved as well. Following a brief description of these international organizations, the most relevant documents are outlined in the next subsection.

\subsection{Present}

\subsubsection{International Context}

The ICAO is an international actor that serves as a collaboration and communication platform for national civil aviation authorities. They are concerned with fundamental regulatory frameworks at a global scale and provide information material, Standards and Recommended Practices with Supporting 
Procedures for Air Navigation Services [1]. In 2016, ICAO published an online toolkit that delivers general guidance for regulators and operators. The same organization further issued recommendations to the safe integration of UAVs into controlled airspace. At this, UAVs are " ( . . ) envisioned to be an equal partner in the civil aviation system [that are] able to interact with air traffic control and other aircraft on a real-time basis" [42]. As this manual particularly focuses on a global harmonization of UAVs in air traffic-controlled environments, lower priority is granted to visual line-of-sight (VLOS) operations [42].

JARUS is a group of 49 national authorities (12/2016) and experts. Founded in 2012, this international actor aims for harmonized standards and provides guidance material to support and facilitate the creation of national UAV regulations. In particular, they recommend operational, safety and technical regulations that notably focus on UAVs that weigh less than $150 \mathrm{~kg}$. Amongst others, current publications include detailed recommendations for light unmanned rotorcraft systems [65], requirements for C2 command and control link [66] and recommendations for personnel licensing [67]. Ongoing work concerns design objectives for detect and avoid systems and operational categorizations.

Besides global acting organizations, diverse stakeholders in the European Union are discussing developments and principles for future regulatory frameworks of UAVs. One important step includes the publication of the Riga Declaration on Remotely Piloted Aircrafts [68] in 2015. This declaration highlights five main principles that should guide the regulatory framework in Europe: (1) Drones need to be treated as new types of aircraft with proportionate rules based on the risk of each operation; (2) EU rules for the safe provision of drone services need to be developed now; (3) Technologies and standards need to be developed for the full integration of drones in the European airspace; (4) Public acceptance is key to the growth of drone service; (5) The operator of a drone is responsible for its use [68].

EASA further developed proposals for common rules for UAV operations [69-71]. The concept of the proposed regulatory framework is based on a proportional and operation-centric approach that focusses on the way and conditions of the operation rather than just on the characteristics of the UAV (i.e., weight) [71]. These actions are accompanied and guided by the European Roadmap for the Integration of Civil Remotely-Piloted Aircraft Systems into the European Aviation System. Published in 2013, this document identifies different levels of harmonization and integration that are addressed with an incremental approach. Furthermore, the roadmap includes three annexes with clear work plans for regulatory improvements, foreseeable research and development contributions and a study on the societal impacts of UAV applications [48].

Next to governmental efforts on national and international levels, UAViators-Humanitarian UAV Network refers to a worldwide initiative with more than 2500 members. Besides other tasks, the initiative developed clear standards for the responsible use of UAVs. Documents and databases are the result of collaborative action of active members. Their code of conduct [72] was drafted in an open consultative process where UAViators members, UAV experts and global acting organizations were involved.

\subsubsection{National Context}

The detailed comparative analysis reveals a clear heterogeneity of national UAV regulations. Except for the variable that addresses VLOS and the lateral distance of the pilot, none of the remaining 19 variables shows any widespread accordance across all cases. However, clusters and similarities between countries become visible as well. The following paragraphs provide a summary of each criterion, highlighting generalities and particularities before certain country-specific contexts and constellations are shown. Evidence is taken from Table 3. 
Table 3. Comparative analysis of 19 national UAV regulations. Light grey cells indicate that the variable is addressed by the UAV regulations. Dark grey cells indicate that the variable is not addressed by the UAV regulations. Additional text outlines further details if applicable.

\begin{tabular}{|c|c|c|c|c|c|c|c|c|c|c|c|c|c|c|c|c|c|c|c|}
\hline \multicolumn{4}{|c|}{ Applicability } & \multicolumn{2}{|c|}{ Technical Requirements } & \multicolumn{8}{|c|}{ Operational Limitations (Distances) } & \multicolumn{3}{|c|}{ Administrative Procedures } & \multirow{2}{*}{$\begin{array}{c}\begin{array}{c}\text { Human } \\
\text { Resources }\end{array} \\
\begin{array}{c}\text { Qualification } \\
\text { of Pilots }\end{array}\end{array}$} & \multicolumn{2}{|c|}{ Ethical Constraints } \\
\hline $\begin{array}{l}\text { Country } \\
\text { Issued and/or } \\
\text { Last Updated } \\
\text { [Reference] }\end{array}$ & $\begin{array}{c}\text { Applicable } \\
\text { for } \\
\text { MA/UAVs }\end{array}$ & $\begin{array}{l}\text { Classification } \\
\text { (Weight, } \\
\text { Purpose, } \\
\text { Area, } \\
\text { Visibility) }\end{array}$ & $\begin{array}{c}\text { Weight } \\
\text { Limits (Max) }\end{array}$ & $\begin{array}{c}\text { Special } \\
\text { Technical } \\
\text { Requirements }\end{array}$ & $\begin{array}{l}\text { Collision } \\
\text { Avoidance } \\
\text { Capability }\end{array}$ & $\begin{array}{c}\text { Airports/ } \\
\text { Strip }\end{array}$ & People & $\begin{array}{c}\text { Congested } \\
\text { Areas }\end{array}$ & $\begin{array}{c}\text { Prohibited } \\
\text { Areas }\end{array}$ & Additional & $\begin{array}{c}\text { Max } \\
\text { Height }\end{array}$ & $\begin{array}{l}\text { VLOS/Lateral } \\
\text { Distance }\end{array}$ & BVLOS & $\begin{array}{c}\text { Application } \\
\text { and } \\
\text { Operational } \\
\text { Certificate }\end{array}$ & $\begin{array}{l}\text { Need for } \\
\text { Registration }\end{array}$ & Insurance & & $\begin{array}{l}\text { In Data } \\
\text { Protection }\end{array}$ & Privacy \\
\hline $\begin{array}{c}\text { United } \\
\text { Kingdom } \\
05 / 2002 \\
03 / 2015 \text { [73] } \\
\end{array}$ & $\mathrm{MA} / \mathrm{UAV}$ & $\mathrm{W}, \mathrm{P}$ & $7 / 20 / 150 \mathrm{~kg}$ & & $\begin{array}{l}\text { for special } \\
\text { operations }\end{array}$ & & $50 \mathrm{~m}$ & $150 \mathrm{~m}$ & & N/A & $122 \mathrm{~m}$ & $\begin{array}{l}500 \mathrm{~m}, \\
\text { EVIOS } \\
\text { possible }\end{array}$ & $\begin{array}{c}\text { need for } \\
\text { special } \\
\text { approval }\end{array}$ & $\begin{array}{c}\text { various } \\
\text { approval } \\
\text { requirements } \\
\text { for different } \\
\text { flight } \\
\text { operations }\end{array}$ & N/A & N/A & $\begin{array}{c}\text { pilot } \\
\text { competency }\end{array}$ & \begin{tabular}{|l} 
refer to \\
Data \\
Protection \\
Act, CCTV \\
Code of \\
Practice \\
\end{tabular} & $\begin{array}{l}\text { advice to } \\
\text { respect } \\
\text { personal } \\
\text { privacy }\end{array}$ \\
\hline $\begin{array}{c}\text { Australia } \\
07 / 202 \\
09 / 2016 \text { [74] } \\
\end{array}$ & $\mathrm{MA} / \mathrm{UAV}$ & $\mathrm{W}, \mathrm{P}$ & $2 / 25 / 150 \mathrm{~kg}$ & N/A & N/A & $5.5 \mathrm{~km}$ & $30 \mathrm{~m}$ & & & $\begin{array}{c}\text { emergency } \\
\text { situation }\end{array}$ & $120 \mathrm{~m}$ & & $\begin{array}{c}\text { need for } \\
\text { special } \\
\text { approval } \\
\end{array}$ & $>2 / 25 \mathrm{~kg}$ & N/A & recommended & $\begin{array}{c}\text { license }>2 \\
\mathrm{~kg}\end{array}$ & $\begin{array}{l}\text { advice to } \\
\text { personal }\end{array}$ & $\begin{array}{l}\text { respect } \\
\text { privacy } \\
\end{array}$ \\
\hline $\begin{array}{c}\text { Malaysia } \\
02 / 2008 \text { [75] }\end{array}$ & no distinction & $\mathrm{W}, \mathrm{P}$ & $20 \mathrm{~kg}$ & $\begin{array}{r}\text { Request equiva } \\
\text { compliance wi } \\
\text { manned a }\end{array}$ & $\begin{array}{l}\text { alent level of } \\
\text { ith rules for } \\
\text { aircraft }\end{array}$ & & N/A & N/A & N/A & N/A & $122 \mathrm{~m}$ & & $\begin{array}{l}\text { if ATC } \\
\text { capable }\end{array}$ & $\begin{array}{l}\text { flight } \\
\text { authorization } \\
\text { and } \\
\text { airworthiness } \\
\text { certification }\end{array}$ & $>20 \mathrm{~kg}$ & & $\begin{array}{l}\text { license for } \\
\text { pilot and } \\
\text { commander }\end{array}$ & $\begin{array}{l}\text { UAV opera } \\
\text { comply w } \\
\text { require }\end{array}$ & $\begin{array}{l}\text { on shall } \\
\text { th civil } \\
\text { ents }\end{array}$ \\
\hline $\begin{array}{c}\text { United States } \\
08 / 2008 \\
06 / 2016[76] \\
\end{array}$ & MA/UAV & $\mathrm{W}, \mathrm{P}$ & $\begin{array}{c}\text { 0,25/25/150 } \\
\mathrm{kg}\end{array}$ & N/A & N/A & $8 \mathrm{~km}$ & & N/A & & N/A & $122 \mathrm{~m}$ & $\begin{array}{l}\text { EVLOS } \\
\text { possible }\end{array}$ & $\begin{array}{c}\text { need for } \\
\text { special } \\
\text { approval }\end{array}$ & $>25 \mathrm{~kg}$ & $\begin{array}{l}\text { registration } \\
\text { number }\end{array}$ & $\begin{array}{l}\text { depending on } \\
\text { purpose }\end{array}$ & certificate & $N / A$ & $\begin{array}{l}\text { refer to } \\
\text { related } \\
\text { laws }\end{array}$ \\
\hline $\begin{array}{l}\text { Canada } 2010 \\
05 / 2015[77] \\
\end{array}$ & MA/UAV & $\mathrm{W}, \mathrm{P}$ & $2 / 25 \mathrm{~kg}$ & N/A & $>25 \mathrm{~kg}$ & $9 \mathrm{~km}$ & $\begin{array}{c}150 \\
\mathrm{~m}\end{array}$ & & & forest fires & $90 \mathrm{~m}$ & & N/A & $>25 \mathrm{~kg}$ & N/A & $\begin{array}{c}\text { depending on } \\
\text { weight }\end{array}$ & $\begin{array}{c}\text { pilot } \\
\text { competency }\end{array}$ & $\begin{array}{l}\text { advice to } \\
\text { personal } \\
\end{array}$ & $\begin{array}{l}\text { respect } \\
\text { privacy }\end{array}$ \\
\hline $\begin{array}{l}\text { France 2012 } \\
12 / 2015[78]\end{array}$ & $\mathrm{MA} / \mathrm{UAV}$ & $\mathrm{W}, \mathrm{A}, \mathrm{V}$ & $2 / 8 / 150 \mathrm{~kg}$ & $>2 \mathrm{~kg}$ & $\begin{array}{l}\text { in } \\
\text { populated } \\
\text { areas and } \\
\text { BVLOS }\end{array}$ & & $\begin{array}{l}\text { not } \\
\text { over } \\
\text { crowds }\end{array}$ & N/A & & $\begin{array}{c}\text { emergency } \\
\text { situation }\end{array}$ & $150 \mathrm{~m}$ & $\begin{array}{l}100 \mathrm{~m} / 200 \\
\mathrm{~m} / \mathrm{EVLOS}\end{array}$ & & $\begin{array}{c}\text { for specific } \\
\text { operation } \\
\text { procedures }\end{array}$ & $\begin{array}{l}\text { depending } \\
\text { on flight } \\
\text { scenario }\end{array}$ & & $\begin{array}{l}\text { depending } \\
\text { on flight } \\
\text { scenario }\end{array}$ & $\begin{array}{l}\text { Commercial } \\
\text { use: ask } \\
\text { for } \\
\text { permission } \\
\text { to use data }\end{array}$ & $\begin{array}{l}\text { advice to } \\
\text { respect } \\
\text { personal } \\
\text { privacy }\end{array}$ \\
\hline $\begin{array}{c}\text { The } \\
\text { Netherlands } \\
2012 \\
07 / 2016[79] \\
\end{array}$ & $\mathrm{MA} / \mathrm{UAV}$ & $\mathrm{W}, \mathrm{P}$ & $\underset{\mathrm{kg}}{1 / 4 / 25 / 150}$ & N/A & N/A & $\begin{array}{l}\text { no fly } \\
\text { zones }\end{array}$ & $50 \mathrm{~m}$ & & & $\begin{array}{c}\text { moving } \\
\text { cars }\end{array}$ & $120 \mathrm{~m}$ & $100 / 500 \mathrm{~m}$ & N/A & $\begin{array}{c}\text { operational } \\
\text { certificate }\end{array}$ & & & license & $\begin{array}{l}\text { refer to } 1 \\
\text { regula }\end{array}$ & $\begin{array}{l}\text { related } \\
\text { tions }\end{array}$ \\
\hline $\begin{array}{c}\text { Germany } \\
12 / 2013 \\
07 / 2016[80]\end{array}$ & UAV & w & $10 / 25 \mathrm{~kg}$ & $>10 \mathrm{~kg}$ & $\begin{array}{l}\text { May help } \\
\text { to get } \\
\text { BVLOS } \\
\text { permission }\end{array}$ & & $\begin{array}{l}\text { not } \\
\text { over } \\
\text { crowds }\end{array}$ & N/A & & $\begin{array}{c}\text { emergency } \\
\text { situation }\end{array}$ & $100 \mathrm{~m}$ & & $\begin{array}{l}\text { need for } \\
\text { special } \\
\text { approval }\end{array}$ & $\begin{array}{c}\text { general } \\
\text { permission, } \\
\text { single } \\
\text { operational } \\
\text { approval for } \\
>10-25 \mathrm{~kg} \\
\end{array}$ & N/A & & $\begin{array}{c}\text { pilot } \\
\text { competency }\end{array}$ & $\begin{array}{r}\text { emphasize tl } \\
\text { might be subj } \\
\text { law }\end{array}$ & $\begin{array}{l}\text { that actions } \\
\text { ject to other } \\
\text { ws }\end{array}$ \\
\hline $\begin{array}{l}\text { Italy 12/2013 } \\
12 / 2015[81]\end{array}$ & UAV & W, A & $2 / 25 / 150 \mathrm{~kg}$ & $\begin{array}{c}\text { For critical } \\
\text { flights }\end{array}$ & N/A & $5 \mathrm{~km}$ & $50 \mathrm{~m}$ & $150 \mathrm{~m}$ & & N/A & $150 \mathrm{~m}$ & $\begin{array}{c}500 \\
\mathrm{~m} / \mathrm{EVLOS}\end{array}$ & $\begin{array}{c}\text { in } \\
\text { segregated } \\
\text { airspace }\end{array}$ & $\begin{array}{c}\text { for critical } \\
\text { operations } \\
\text { and } / \text { or }>25 \mathrm{~kg}\end{array}$ & $\begin{array}{l}\text { plate and } \\
\text { electronic } \\
\text { ID }\end{array}$ & & $\begin{array}{c}0-25 \mathrm{~kg} \\
\text { certificate, } \\
>25 \mathrm{~kg} \\
\text { license } \\
\end{array}$ & $\begin{array}{c}\text { refer to } \\
\text { Italian } \\
\text { Data } \\
\text { Protection } \\
\text { Code } \\
\text { Code }\end{array}$ & N/A \\
\hline $\begin{array}{c}\text { Austria } \\
01 / 2014 \\
08 / 2015[82]\end{array}$ & $\begin{array}{l}\text { no distinction } \\
\text { and if }>500 \mathrm{~m} \\
\text { from pilot }\end{array}$ & W, A & $5 / 25 / 150 \mathrm{~kg}$ & $\begin{array}{l}\text { depending } \\
\text { on scenario }\end{array}$ & $\begin{array}{c}\text { depending } \\
\text { on } \\
\text { scenario }\end{array}$ & & $\begin{array}{l}\text { not } \\
\text { over } \\
\text { crowds }\end{array}$ & N/A & & N/A & $150 \mathrm{~m}$ & & $\begin{array}{l}\text { need for } \\
\text { special } \\
\text { approval }\end{array}$ & $\begin{array}{c}\text { general } \\
\text { permission, } \\
\text { single } \\
\text { approval for } \\
\text { risky } \\
\text { operations }\end{array}$ & $\begin{array}{l}\text { registration } \\
\text { needed }\end{array}$ & & $\begin{array}{c}\text { depending } \\
\text { on } \\
\text { scenario }\end{array}$ & N/A & N/A \\
\hline
\end{tabular}


Table 3. Cont.

\begin{tabular}{|c|c|c|c|c|c|c|c|c|c|c|c|c|c|c|c|c|c|c|c|}
\hline \multicolumn{4}{|c|}{ Applicability } & \multicolumn{2}{|c|}{ Technical Requirements } & \multicolumn{8}{|c|}{ Operational Limitations (Distances) } & \multicolumn{3}{|c|}{ Administrative Procedures } & \multirow{2}{*}{$\begin{array}{c}\begin{array}{c}\text { Human } \\
\text { Resources }\end{array} \\
\begin{array}{c}\text { Qualification } \\
\text { of Pilots }\end{array}\end{array}$} & \multicolumn{2}{|c|}{ Ethical Constraints } \\
\hline $\begin{array}{l}\text { Country } \\
\text { Issued and/or } \\
\text { Last Udated } \\
\text { [Reference] }\end{array}$ & $\begin{array}{l}\text { Applicable } \\
\text { for } \\
\text { MA/UAVs }\end{array}$ & $\begin{array}{l}\text { Classification } \\
\text { (Weight, } \\
\text { Purpose, } \\
\text { Area, } \\
\text { Visibility) }\end{array}$ & $\begin{array}{c}\text { Weight } \\
\text { Limits (Max) }\end{array}$ & $\begin{array}{c}\text { Special } \\
\text { Technical } \\
\text { Requirements }\end{array}$ & $\begin{array}{l}\text { Collision } \\
\text { Avoidance } \\
\text { Capability }\end{array}$ & $\begin{array}{c}\text { Airports/ } \\
\text { Strip }\end{array}$ & People & $\begin{array}{c}\text { Congested } \\
\text { Areas }\end{array}$ & $\begin{array}{c}\text { Prohibited } \\
\text { Areas }\end{array}$ & Additional & $\begin{array}{l}\text { Max } \\
\text { Height }\end{array}$ & $\begin{array}{l}\text { VLOS/Lateral } \\
\text { Distance }\end{array}$ & BVLOS & $\begin{array}{l}\text { Application } \\
\text { and } \\
\text { Operational } \\
\text { Certificate }\end{array}$ & $\begin{array}{l}\text { Need for } \\
\text { Registration }\end{array}$ & Insurance & & $\begin{array}{l}\text { Data } \\
\text { Protection }\end{array}$ & Privacy \\
\hline $\begin{array}{c}\text { Spain } \\
\text { 10/2014 [83] }\end{array}$ & MA/UAV & w & $2 / 25 / 150 \mathrm{~kg}$ & $\mathrm{~N} / \mathrm{A}$ & $\mathrm{N} / \mathrm{A}$ & $8 / 15 \mathrm{~km}$ & $\begin{array}{l}\text { not } \\
\text { over } \\
\text { groups }\end{array}$ & & & N/A & $120 \mathrm{~m}$ & $\begin{array}{l}500 \mathrm{~m} \text { for } \\
2-25 \mathrm{~kg}\end{array}$ & $\begin{array}{c}0-2 \mathrm{~kg} \text { or } \\
\text { special } \\
\text { approval }\end{array}$ & $\begin{array}{l}\text { flight } \\
\text { authorization, } \\
\text { NOTAM } \\
\text { notification }\end{array}$ & $\begin{array}{l}\text { registration } \\
\text { and ID } \\
\text { plate }\end{array}$ & & $\begin{array}{c}0-25 \mathrm{~kg} \\
\text { certicicate, } \\
>25 \mathrm{~kg} \\
\text { license }\end{array}$ & N/A & N/A \\
\hline $\begin{array}{c}\text { Azerbaijan } \\
01 / 2015 \text { [84] } \\
\end{array}$ & no distinction & w & 20/150 kg & N/A & for BVLOS & & $50 \mathrm{~m}$ & $150 \mathrm{~m}$ & & N/A & $122 \mathrm{~m}$ & & $\begin{array}{c}\text { in } \\
\text { segregated } \\
\text { airspace }\end{array}$ & $\begin{array}{c}\text { for critical } \\
\text { operations } \\
\text { and } / \text { or }>20 \mathrm{~kg} \\
\end{array}$ & $>20 \mathrm{~kg}$ & & $\begin{array}{c}\text { pilot } \\
\text { competency }\end{array}$ & N/A & N/A \\
\hline $\begin{array}{l}\text { Chile } \\
\text { 04/2015 [85] }\end{array}$ & no distinction & w & $6 \mathrm{~kg}$ & $\begin{array}{l}\text { many special } \\
\text { demands }\end{array}$ & N/A & $2 \mathrm{~km}$ & $30 \mathrm{~m}$ & N/A & & $<60 \min$ & $130 \mathrm{~m}$ & $500 \mathrm{~m}$ & N/A & $\begin{array}{l}\text { flight } \\
\text { authorization }\end{array}$ & & N/A & license & N/A & N/A \\
\hline $\begin{array}{c}\text { Colombia } \\
07 / 2015[86] \\
\end{array}$ & & w & $25 \mathrm{~kg}$ & $\begin{array}{c}\text { many special } \\
\text { demands }\end{array}$ & N/A & $5 \mathrm{~km}$ & & & & $\begin{array}{l}\text { intern. } \\
\text { border }\end{array}$ & $152 \mathrm{~m}$ & $750 \mathrm{~m}$ & N/A & $\begin{array}{c}\text { flight } \\
\text { authorization }\end{array}$ & & & license & $\begin{array}{l}\text { not allowed } \\
\text { the rights }\end{array}$ & $\begin{array}{l}\text { to violate } \\
\text { f privacy }\end{array}$ \\
\hline $\begin{array}{l}\text { South Africa } \\
09 / 2015 \text { [87] }\end{array}$ & N/A & $\mathrm{w}, \mathrm{v}$ & $7 / 20 \mathrm{~kg}$ & & $\mathrm{~N} / \mathrm{A}$ & $10 \mathrm{~km}$ & $50 \mathrm{~m}$ & & & N/A & $122 \mathrm{~m}$ & $\begin{array}{l}\text { EVLOS } \\
\text { possible }\end{array}$ & $\begin{array}{c}\text { need for } \\
\text { special } \\
\text { approval }\end{array}$ & $\begin{array}{l}\text { air service } \\
\text { license, letter } \\
\text { of approval } \\
\text { and operation } \\
\text { certificate }\end{array}$ & $\begin{array}{l}\text { registration } \\
\text { marks }\end{array}$ & & license & N/A & N/A \\
\hline $\begin{array}{c}\text { Japan } \\
12 / 2015[88] \\
\end{array}$ & $\begin{array}{l}\text { no distinction } \\
\text { and if heavier } \\
\text { than } 200 \mathrm{~g} \\
\end{array}$ & N/A & N/A & N/A & N/A & $\begin{array}{l}\text { no fly } \\
\text { zone }\end{array}$ & $30 \mathrm{~m}$ & & & $\mathrm{~N} / \mathrm{A}$ & $150 \mathrm{~m}$ & & $\mathrm{~N} / \mathrm{A}$ & $\begin{array}{l}\text { for restricted } \\
\text { areas }\end{array}$ & $\mathrm{N} / \mathrm{A}$ & $\mathrm{N} / \mathrm{A}$ & N/A & $\mathrm{N} / \mathrm{A}$ & N/A \\
\hline $\begin{array}{c}\text { Nigeria } \\
\text { 12/2015 [89] } \\
\end{array}$ & no distinction & N/A & N/A & N/A & N/A & N/A & N/A & N/A & N/A & $\begin{array}{c}\text { special } \\
\text { authorizatiog }\end{array}$ & N/A & & & $\begin{array}{c}\text { flight } \\
\text { authorization }\end{array}$ & N/A & N/A & $\begin{array}{l}\text { manned } \\
\text { aircraft } \\
\text { license }\end{array}$ & license & N/A \\
\hline $\begin{array}{l}\text { Rwanda } \\
05 / 2016[90]\end{array}$ & $\begin{array}{c}\text { not for toy } \\
\text { aircraft }\end{array}$ & N/A & $25 \mathrm{~kg}$ & N/A & N/A & $10 \mathrm{~km}$ & $50 \mathrm{~m}$ & & & $\mathrm{~N} / \mathrm{A}$ & $100 \mathrm{~m}$ & $300 \mathrm{~m}$ & & $\begin{array}{c}\text { flight } \\
\text { authorization, } \\
\text { operational } \\
\text { certificate }\end{array}$ & $\begin{array}{l}\text { registration } \\
\text { marks }\end{array}$ & & license & $\begin{array}{l}\text { respect privea } \\
\text { surveilance } \\
\text { and proper } \\
\text { their cor } \\
\text { prohil }\end{array}$ & $\begin{array}{l}\text { yo of ohers } \\
\text { of people } \\
\text { y without } \\
\text { sent is } \\
\text { ited }\end{array}$ \\
\hline $\begin{array}{l}\text { China } \\
\text { 09/2016 [91] }\end{array}$ & no distinction & N/A & $7 \mathrm{~kg}$ & N/A & & & N/A & & & $\begin{array}{l}10 \mathrm{~km} \text { to } \\
\text { other } \\
\text { aircrafts }\end{array}$ & N/A & & N/A & $\begin{array}{c}\text { flight } \\
\text { authorization } \\
\text { and } \\
\text { operational } \\
\text { certificate } \\
\end{array}$ & registration & $\mathrm{N} / \mathrm{A}$ & certification & N/A & N/A \\
\hline
\end{tabular}




\section{Applicability}

In general, UAV regulations only apply for certain scenarios of civil UAVs that are classified and limited by the weight of the UAV and/or the area, operational range or purpose of its utilization. As a matter of the objective of this research, all regulations are applicable for UAVs that are used for commercial purposes. Most of the countries define commercial flight operations as flights for purposes others than just for the flight itself. Here, a mounted camera can already indicate commercial use (e.g., Austria). However, 15 countries also include the regulations of UAVs for fun and recreational purposes whereof more than half of the countries do not distinguish any purpose and thus include both uses. Only four countries explicitly exclude UAVs for non-commercial uses. This initial definition of the applicability is further reflected in different safety levels for respective uses. The same applies for another classification criteria: weight. All countries except of Japan, China, Rwanda and Nigeria have a classification scheme according to the weight and thus follow the basic concept of a risk-based approach — the higher the associated risk (i.e., weight) the stricter the flight conditions.

Regarding weight limitations, only two countries-U.S. and Japan-introduce a minimum threshold: $250 \mathrm{~g}$ and $200 \mathrm{~g}$, respectively. All drones that are lighter than the threshold are not subject to the regulations. In contrast, almost all countries incorporate a maximum take-off mass (MTOW) - indicated in italics in Table 3. At this, UAVs that are heavier than $150 \mathrm{~kg}$ are usually not regulated by national aviation authorities but by international bodies like EASA in Europe; this group of UAVs is usually regulated in a similar way as manned aircrafts [69]. However, the MTOW is not consistent in all cases. Here, China and Chile are extreme cases that allow comparatively low MTOWs. Other predominant weight thresholds refer to $20 / 25 \mathrm{~kg}$ and $\leq 10 \mathrm{~kg}$. The presence of weight classes allows for multi-layered regulations that are adopted to the associated risk. This approach allows for further differentiations regarding administrative procedures and requirements for pilot qualifications.

Next to the classification according to the weight, Austria, France and Italy include the area of the intended flight as a second criterion. As a consequence, these countries create different scenarios that are compiled in a more complex risk-matrix (cf. Austria). France and South Africa also incorporate visibility in their scheme. Consequently, beyond visual line-of-sight flights are already considered as one flight scenario.

\section{Technical Prerequisites}

Besides general recommendations for pre-flight checks of all technical functionalities, 12 out of 19 countries mention special technical instruments as prerequisites for UAV operations. Here, the Latin American representatives Chile and Colombia stand out for very extensive and concrete requirements that encompass the material of the blades, the GNSS device, command and control requirements, and the autopilot and recovery capabilities, just to name a few. In contrast, the remaining ten countries mainly demand special technical arrangements if the flight operation is classified as risky by either exceeding a certain MTOW and/or being operated in populated areas. In six cases, main requirements concern the command and control system and special failure and safety instruments like parachutes that are able to safely terminate the flight in emergency situations like malfunction or loss of command and control links (e.g., in France and Italy).

In addition to general requirements, collision avoidance capabilities were chosen as a separate variable as it is currently widely discussed for the safe integration of UAVs into national airspace systems [92]. In manned aircraft aviation the pilot observes whether other users of the airspace are on a collision path and adjusts the airplane and flight if necessary. As UAVs are operated without any pilot on board, the 'see and avoid' concept of manned aircrafts can no longer be fulfilled. Especially in cases where UAVs are operated beyond visual line-of-sight (BVLOS), substitutes like special technical instruments may become necessary in order to achieve an equivalent level of safety. In this comparative analysis, only seven cases particularly mention sense and avoid, see and avoid or detect and avoid requirements, respectively. However, these mandates are only applicable in particular operational conditions like flights in controlled airspace (UK), BVLOS (France) or UAV operations above a certain 
MTOW (Canada). In all cases, respective requirements remain very general. The U.S. further outlines the reasoning behind not incorporating any collision avoidance requirements into their regulations as the technology is still in its early stage and none of the instruments has an airworthiness certification so far [93].

\section{Operational Limitations}

Operational limitations are the main criteria of most UAV regulations and refer to restrictions of the UAV flight. Apart from Nigeria, all countries have defined horizontal distances to people and property, or so-called no-fly zones, which need to be taken into account. The most prominent example of such a no-fly zone is the surrounding of aerodromes, airports and airstrips. As UAVs pose a serious risk for manned aircrafts, they are usually not allowed to fly in controlled airspace and thus in the proximity of places where manned aircrafts land or take off-special authorization might be possible on a case-by-case basis. Besides the prohibition to operate UAVs in controlled airspace, some countries define additional no-fly zones that can be retrieved from online map services (e.g., Japan, the Netherlands). Another important operational limitation states a safe distance to people, property and vessels that are not associated with the UAV flight itself. Here, ten countries specifically mention minimum lateral distances in the range of $30 \mathrm{~m}$ to $150 \mathrm{~m}$ to people. Six countries raise a general prohibition to fly in the vicinity of people and/or crowds of people. The remaining countries, Nigeria, China and Malaysia, do not discuss operational limitations related to people.

One hierarchal level higher than prohibitions to fly over people refers to flight regulations over congested areas such as towns, cities and roads. Here, 12 countries prohibit UAV flights over these areas-some even include a minimum distance needing to be kept. However, terms like congested areas as well as crowds of people remain vague and expressions are rarely defined. In contrast, the extent of restricted areas is very sharp and includes UAV flights over jails, military areas, industrial buildings, nuclear power plants, hospitals, and/or governmental buildings, respectively. All cases, except in Malaysia and Nigeria, incorporate these kinds of prohibited areas into their legal framework. In addition to permanent restricted areas, emergency situations like operations of the police or fire brigades might be subject to temporal UAV flight restrictions (e.g., Australia, Germany). More exceptional operational limitations refer to a maximum flight time of 60 min (Chile), a restricted distance of $9.2 \mathrm{~km}$ towards all international borders (Colombia), or a specified distance of $10 \mathrm{~km}$ to any other aircraft (China).

Besides flight restrictions due to the location of the UAV operation, general limitations refer to a maximum height level and horizontal distances in terms of visibility and range. Regarding the height level, all cases apart from China and Nigeria allow only low-altitude flights and define a maximum flying height within the range of minimum $90 \mathrm{~m}$ (Canada) to maximum $152 \mathrm{~m}$ (Colombia) above ground level. These particular heights can be explained by the fact that UAV regulations currently aim to separate manned aircrafts and UAVs - and thus allow UAV flights only below the minimum safe altitude for aircrafts. Besides international recommendations by ICAO, the value for minimum safety altitude changes in different national contexts, e.g., the U.S., defines non-congested areas as up to 500 feet (152 m) AGL (Federal Aviation Regulations, Sec. 91.119). Regarding the horizontal distance of UAVs to the pilot, regulatory bodies usually distinguish between two ranges: VLOS and BVLOS (see Figure 5). All cases of the comparative analysis allow UAV flights in VLOS. In VLOS conditions, the pilot must be able to maintain direct unaided visual contact to the UAV [42]. In addition to this definition, eight countries designate maximum horizontal distances that range from minimum $100 \mathrm{~m}$ in France to maximum $750 \mathrm{~m}$ in Colombia. The required distance bounds a vague interpretation of the term VLOS. Some cases further include extended visual line-of-sight (EVLOS) operations. Here, the pilot uses an additional observer or remote pilots to keep the visual contact to the UAV (cf. Figure 5). The US, UK, Italy, Spain and South Africa particularly mention the possibility of EVLOS operations within their UAV regulations. Furthermore, 13 out of 19 countries basically allow BVLOS flights. 
However-apart from Spain, France and Nigeria—BVLOS flights are outside the scope of the UAV regulations as such and thus require either special flight conditions or exceptional approvals.

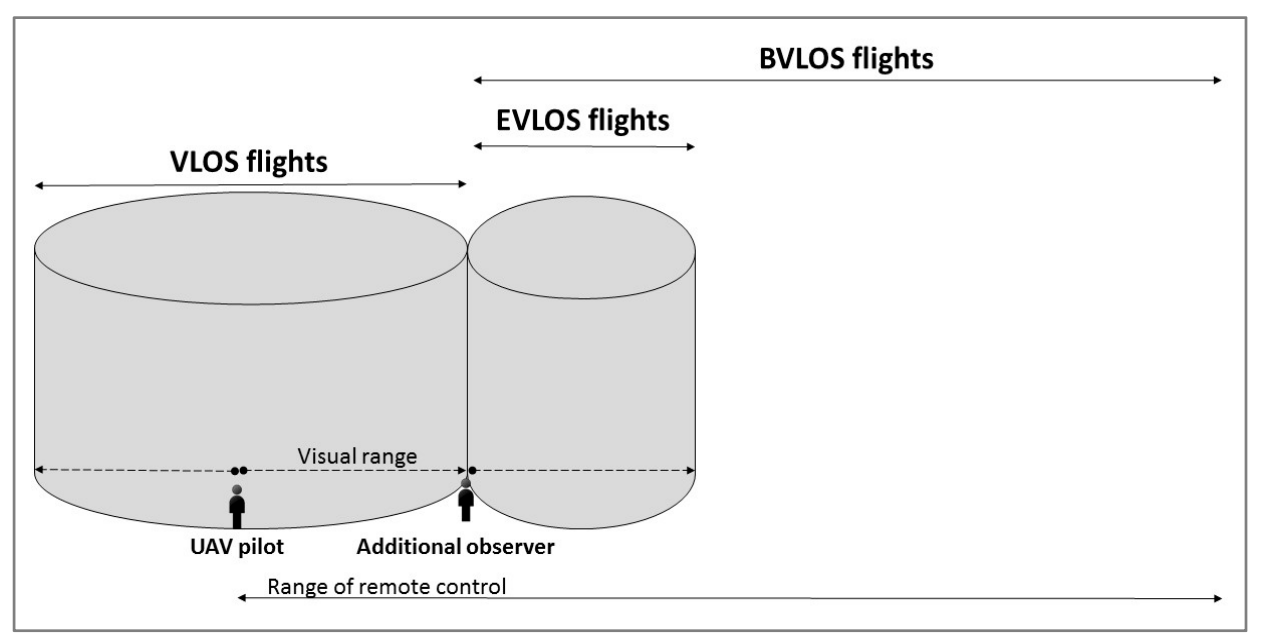

Figure 5. Schematic distinction between UAV flight ranges—visual line-of-sight (VLOS), extended visual line-of-sight (EVLOS) and beyond visual line-of-sight (BVLOS), based on [87].

\section{$\underline{\text { Administrative Procedures }}$}

The criteria of administrative procedures distinguishes variables according to the application process, the need for UAV registration and the need for insurance coverage. Here, a marked heterogeneity can be observed. In general, the amount of effort to apply for flight permission depends on the complexity of the UAV operations. Due to the initial classification of different UAV operation scenarios, nearly all application procedures are multi-layered, and various strategies have to be followed in different contexts. To provide a comparable basis, the following results are grounded on best-case scenarios where the UAV flight meets all operational prerequisites and does not fall under special approval conditions-if not mentioned otherwise. Pursuant to this assumption, huge differences become visible: some countries do not envisage any application procedures for UAV operations below a certain MTOW—neither for the registration of the platform nor for a flight approval. In contrast, others follow a single-case flight authorization approach that entails a new application for each flight operation. Australia, Italy and Canada do not require a formal flight application if the UAV does not exceed a MTOW of $25 \mathrm{~kg}$. Others demand applications if the flight is intended to happen in areas that do not conform to standard operational procedures (Japan, France, UK). Light UAVs in Austria and Germany are subject to a general permission which is granted for a specified timeframe. In six cases, UAV flight permissions encompass single-case application procedures.

In addition to official and formal flight permission procedures at respective national aviation authorities, notifications and local flight approvals are common praxis for the majority of cases. Based on the regulatory texts, the approval and notification procedure follows four main purposes: (1) to acknowledge specific local operational restriction; (2) to impede conflicts of airspace users; (3) to avoid concerns and interruptions from the public; and (4) to allow surveillance of the intended UAV flight. Furthermore, declarations of compliance to applicable sections in the UAV regulations can also be mandatory before flight permission is granted (e.g., Italy, Spain, UK). If the flight will be (partly) executed in controlled airspace, a notification to the air traffic control service is compulsory in all cases that are compared. At this, Spain stands out as a special case: all commercial UAV flights involve a special notification to airman (NOTAM) regardless of whether the UAV enters controlled or non-controlled airspace.

Besides the notification to other airspace users, announcements to the local police as well as the approval by the land owner where the UAV is about to take-off and land are obligatory (e.g., Germany). 
At this point, search and rescue operations by fire brigades or UAV operations of governmental institutions are usually exempt from these formal application procedures.

Next to the application procedure, eleven cases require a registration for any kind of commercial flight operation. Here, the registration either involves a registration number, markings, or an electronic ID plate (e.g., Italy). Aviation authorities in Malaysia and Azerbaijan require a registration only if the weight of the UAV exceeds $20 \mathrm{~kg}$. Six cases do not embrace any registration process.

Insurance obligations are further considered within the majority of UAV regulations of this analysis. An insurance basically addresses the subject of a clear liability regime that is able to sufficiently compensate for any harm or damage caused by the flight operation [40]. However, in six out of 19 UAV regulations, an adequate insurance policy is not treated as a compulsory requirement for UAV flights.

Human Resource Requirements

Besides the UAV itself, many regulations include demands upon the UAV pilot. Here, practical training, theoretical knowledge tests, aeronautical tests, and medical assessments encompass the most common requirements. Just as with application procedures, the level of required pilot skills usually depends on the complexity and the risk of the flight mission. So far, Japan does not mention any pilot needs and Azerbaijan, UK and Germany only request a basic confirmation of the competencies of the UAV pilot. Besides this, the majority of the cases either demand a pilot certification or a license. The main difference between both is grounded in the amount of training that is attached to the issuance of the degree (cf. Italy). A certificate is usually granted by intermediaries like authorized training centres or UAV manufacturers and entails a basic practical and theoretical training of the pilot. In contrast, the procedure to obtain a UAV pilot license generally involves an assessment of aeronautical background knowledge, practical examinations and medical tests. A pilot license is usually issued by national aviation authorities. However, a sharp distinction between both pilot qualifications is not possible and some countries choose "middle ways" and refer either to certificates or licenses. In this comparison, Malaysia and Nigeria are exceptional cases. A UAV operation in Malaysia requires two persons-a pilot and a commander. Both shall hold a valid pilot license. In Nigeria, the UAV pilot needs to be licensed to operate manned aircrafts in order to be authorized to execute UAV flights.

\section{Implementation of Ethical Constraints}

The aspect of privacy and data protection in relation to the increasing use of UAVs underlines one currently widely discussed topic [39,51]. UAVs can be equipped with multiple payloads such as imaging equipment or transmitters which can easily capture and record data of people, houses or other objects and thus potentially violate privacy and data protection rights of citizen. Based on the outcomes of this comparative analysis, these aspects are barely incorporated and reflected in current UAV regulations. Only 12 cases mention privacy and/or data protection. Here, the majority of cases "only" advise to respect personal privacy. Furthermore, many cases state that actions might be subject to other laws and that national and international applicable legislations need to be followed. However, only five countries directly refer to respective laws. Rwanda particularly incorporates the prohibition of surveillance activities without people's consent into their UAV regulations.

\section{Country Context and Pattern}

The comparison of variables of all 19 cases reveals a heterogeneous picture. Even though all countries except for Azerbaijan, Chile, Nigeria and Rwanda are part of JARUS, no coherent concept or strategy for national UAV regulations can be identified. Particularly striking examples are Japan and Nigeria, as more than half of the variables were not addressed by their legal frameworks. One would now suggest that both cases are similar. However, the opposite is the case. Without tangible technical and human resource requirements, UAV flights in Japan can easily be commenced within given operational and geographical restrictions. In Nigeria, no general operational limitations or technical requirements are stated. Nonetheless, each flight needs a special authorization and the pilot requires 
a manned aircraft license which involves a very elaborate procedure and impedes widespread usage of UAVs. In contrast, France, Italy and Austria acknowledge nearly all variables in their regulations. In all three cases, the regulations show a certain maturity as different scenarios and a complex risk-based classification is recognized. Technical and administrative requirements as well as operational restrictions are formulated according to the risk of the flight operation. All other cases exclude the area of interest as one classification criterion and mostly refer to special approval procedures if one intends to fly in usually restricted areas-such as developed and inhabited areas.

Regarding the temporal aspect—date of release or last update-all UAV regulations except those of Spain and Malaysia were either issued or updated in the last two years (2015 and 2016). All cases that show updates since the first release tend to involve lower administrative procedures and lower demands for pilot qualification for risk-less UAV operations within respective limitations. During the online search and investigations of the authors, different levels of the provision of information about respective UAV regulations became prevalent. Except for Malaysia, all cases characterized by early releases before 2012 show active public relations activities, dissemination and awareness campaigns of respective regulatory frameworks including clear homepages that provide insightful infographics and online templates for notification forms. Besides this, a few countries like the US and the Netherlands already embrace different kinds of media and platforms to raise the consciousness of mandatory pre-flight requirements and operational limitation for UAV flights (e.g., [94-96]).

\section{Discussion}

The following subsections synthesize the outcomes of the research investigation and aim to predict possible future trends. Here, the first part sketches identifiable trends that are based on the comparative analysis of 19 national UAV regulations. In contrast, the second part emphasizes developments in the broader field of law and technology in regard to legal UAV frameworks: the aim is to position current and possible future developments in a wider contextual setting. The final subsection highlights limitations of this research.

\subsection{Future Trends and Challenges}

The current state of UAV regulatory frameworks constitutes a major focus for many stakeholders in the domain [97], and the heterogeneity of national UAV regulations shows varying approaches in response to the demands of various interest groups. However, commonalities are present and recent changes in some national UAV regulations allow for the prediction of possible future developments and challenges. For example, civil UAV operations in both controlled and uncontrolled airspace are largely restricted and this will continue to impede wider utilization, at least in the short term.

The key challenge appears to be to find an optimum balance between the demands of the various actors; allowing for innovation on the one hand, but at the same time ensuring recognition and support for safety, fundamental human rights and civil liberties. The future development of civil UAV use will ultimately involve multiple interest groups and various motivations [98,99]. Government institutions and regulatory bodies that hold political mandates want to ensure public safety and security, civil liberties, but also to promote UAV innovation and technology innovation more generally. Stakeholders in research strive for UAV technical advancement. Hardware and software manufacturers aim to sell products and are interested in lowering market barriers and opening up new application areas. End users have their own needs and market interests according to their priorities.

In both national and international contexts, a risk-based approach to regulate the use of UAVs appears to be the strategy of choice. An initial step towards risk-based assessments and requirements is acknowledged through weight classifications: it is already evident in the majority of cases. However, the inclusion of other parameters such as area, purpose, and visibility provides an even more proportional approach. Following this, an all-embracing framework would ultimately allow the streamlining of regulations for all kinds of civil UAV operations and to disentangle complicated requirements for special exemptions and waivers. If a UAV flight can be considered as riskless 
(i.e., lightweight, in uninhabited areas and VLOS), or extremely low risk, no bureaucratic barriers should impede it simply for the sake of bureaucracy. The more risky the flight operation, the more requirements are applicable. This is in-line with current national harmonization actions undertaken by EASA where riskless open and more risky specific categories are defined [70]. France, Italy and Austria already follow a risk-based approach and in this regard can be considered as pioneering countries.

Grounded in this risk-based approach, detailed safety requirements for various scenarios can be inbuilt into the regulatory framework [97]. Damage to physical objects or injuries of people on the ground caused by UAVs are threats to public safety. They may be the result of technical malfunction or inadequate maintenance of equipment, mid-air collisions, or misuse by its operator. With regard to the growing UAV market and activity levels, the requests for approvals for flights are certain to increase. In this context, aviation authorities would presumably prefer to avoid treating every request as a stand-alone request: the administrative time and expense would overwhelm bureaucracies and undermine any policies intended to promote technological innovation. Increased efficiency and capacities to deal with the administrative processes of flight approvals and UAV platform registration are necessary. In addition to this, general flight permissions for low-risk UAV operations in uncontrolled airspace, such as in large parts of Australia and Canada, can be seen as pioneering. However, additional (in the best case, online) notification forms-with details of the date, time and place of the intended UAV operation-are important in order to allow the safe and efficient management of respective airspace and to help avoid mid-air UAV collisions. In this regard, it is evident that countries with a long history of frequently updated UAV regulations show more maturity than countries that first implemented regulations only in 2015/16. Here, maturity can be seen as leading to efficient administrative processes, the presence of awareness campaigns and established procedures to register UAVs and to train UAV pilots. Next to the more obvious causes of failure of UAV operations, unencrypted signals leave UAVs open to cyber-attacks and hacking. Here, manufacturers are expected to take action in order to increase the security aspects of their UAV. Besides others, encrypted signals of the command and control links are possible means to widely impede unintentional interferences [42].

Besides administrative procedures, accountability addresses another key aspect when it comes to UAVs and public safety. The responsibility of the operator lasts for the entire flight mission and thus involves being aware of and adhering to legal regulations from the beginning of the UAV mission. However, UAV regulations can hardly be found in print, let alone on the homepages of aviation authorities. This situation was found in some countries in which information services and consulting initiatives were only present in a few cases. Given the political will to foster the use of civil UAVs, educational modules, easily accessible information services and awareness campaigns that simply explain prevailing legal norms need to be developed, promoted, and made readily accessible. Lessons learned, best practices, but also the awareness of consequences of misuse, can contribute to reassure the public, thereby creating trust. As well as accountability in general, auditing of the platform and pilot is necessary in order to investigate what happened in case of an accident and to hold the responsible person accountable. This can only be achieved if the UAV platform carries unique identifiers like registration numbers or special ID plates. Although platform registration schemes are in place in many countries, this requirement is also likely to become mandatory for the remaining countries. Once the UAV—and consequently also the pilot—can be identified after an incident that causes injury to people or damage to property, sufficient insurance coverage must be available in order to compensate for injury or damage. Accordingly, the financial risk of operating UAVs is transferred from the operator to the insurer. However, insurance companies impose their own conditions relating to UAV operations and thus can set more requirements than mandated by national legal frameworks. As liability refers to one main concern, mandates for apportioned insurance coverage and therefore the influence of insurance companies in regulating UAV operations are expected to grow. Besides the definitive liability of the use of UAVs, liability for design and construction of UAVs are foreseeable aspects for future debates as a legal basis still has to be defined. A clear divide of responsibilities 
amongst those involved becomes particularly necessary when the degree of automation of UAV flights increases [100].

With regard to the growing number of UAV operations, on-board communication devices can play a vital role for BVLOS - and even beyond radio line-of-sight flights-to avoid mid-air collisions. Nokia [101] is an example of a firm that is currently developing technology for UAV-based traffic management. It is conceivable that UAVs in non-segregated airspace need to be equipped with communication devices that allow for safe operations in relation to other airspace users-both manned and unmanned aircraft. Central flight coordination services must know where, when and which UAV is flying at each point in time in order to monitor and safely manage all operations. In this regard, it is very likely that the law will respond to such technological developments and set requirements for on-board devices. Accordingly, it seems most likely UAVs that are not equipped with special communication techniques will only be allowed to fly in segregated airspace, i.e., in UAV test centres or special zones for private users who wish to use UAVs for recreational purposes.

It is evident that the ability of UAVs to collect information on individuals and private places may infringe the right to privacy and questions the protection of personal data. Following the outline of relevant publications $[37,45,98,100,102]$ and supported by the results of this comparative analysis, the challenge of data protection and the right to privacy is hardly being addressed in any of the national and international UAV regulations so far. However, a broad scientific discourse has already been initiated and this topic continues to gain in importance. Although national and international laws and regulations are mostly in place and implicitly deal with these ethical concerns, two main problems remain: (1) gaps in the respective laws and regulations governing the use of UAVs $[100,102]$; and (2) the lack of awareness about the applicability of data protection and privacy rules [37,102]. The characteristics of UAVs-being both low cost in operation and small in size-make it very difficult to control and track them in order to ensure lawful use and to hinder targeted observations and surveillance by individuals. Moreover, data collection by UAVs remains invisible in most of the cases and the data subject is rarely aware of the fact that their data is being collected [46]. Without knowledge about the operator, purpose of the flight and sensing equipment the UAV is equipped with, individuals face big challenges to enforce their rights [37]. All possible threats to the right of privacy and the use of personal data captured by UAVs should be assessed in order to adequately incorporate them into national privacy and data protection laws. Furthermore, following the outline of [100], distinct boundaries for UAV operators and strict limitations regarding the ownership and further storage and dissemination of collected data need to be clearly addressed in respective regulatory frameworks. In order to reach full compliance with legal demands, awareness-raising actions and communications between industry, users and the general public need to be stimulated. In addition to this, easily accessible information platforms and soft law measures that are subject to guides, code of conducts and impact assessments on privacy are important tools to adequately address challenges to fundamental rights in regard to the utilization of UAVs. Privacy by design [102,103] might also be a future option and refers to design-specific technically embedded data protection measures.

Much effort is being devoted by international organizations to formulate common standards such as prescriptive requirements for UAV operations [1], technical standards for UAVs [65], and pilot licensing recommendations [67]. However, implementation of and links to national regulatory frameworks remain limited. Examples include the JARUS standards of light rotorcraft UAVs [104] or the evolution of VLOS and BVLOS flights as defined in the European roadmap [48]. According to the latter, VLOS operation over populated areas should by now have already reached the ultimate goal of successful integration into non-segregated airspace. However, only a few countries envisage UAV operations in populated areas without exceptional permission. The same applies for BVLOS flights, which are rarely mentioned in national UAV regulations, but should by now have reached a certain level of national/international integration [48]. This is mainly attributed to technological causes, because an equivalent level of collision avoidance capabilities is yet to be developed. However, the efforts of the EASA in the promotion of common EU rules for UAVs might result in the first 
internationally harmonized UAV regulations in the next 5-10 years. Besides the European context, international recommendations, such as those from ICAO and JARUS, are expected to gain in relevance as they play a crucial role to pave the way for the convergence of national regulations towards international harmonized standards.

\subsection{Unmanned Aerial Vehicles (UAVs) in the Broader Context of Law and Technology}

Apart from foreseeable future developments of national and international UAV regulations, "history has shown us that some of the greatest obstacles facing the realisation of a new technology are not always technical in nature but are often related to its integration into society" [99]. Clothier et al. [99] reviewed the developments of the regulations of early automobiles in the UK and present insights about the risk management of new technologies in general. In this context, resentments, conspicuous drawbacks, limited public knowledge about the technology and threatened industrial competitors paved the way for the very precautionary formal regulations of automobiles in the UK (cf. "Red Flag Law" 1865 [99]). For 30 years, this law blocked further technological developments in the UK, leaving other countries to benefit from pioneering. Only in 1930 was a comprehensive law including regulations on construction, weight, driver licensing, insurance obligations, and penalties defined. Although some differences exist, Clothier et al. [99] show clear parallels with current UAV regulations which allow for hypotheses about future regulatory developments in a broader context.

Existing proscriptive and prescriptive legal frameworks for UAVs are expected to change in the future. However, due to the on-going emergence of new UAV technology, slowly adapting existing UAV regulations are of limited suitability in keeping the link to current developments [53]. The main problems concern the constant need to address new potential harms, risks and negative impacts [105]. Therefore, soft laws as alternative means of rulemaking may also play a critical role in order to adequately address the gaps left by formal regulation. Here, distinguishing between co-regulation, industry self-regulation and organisational self-regulation-which result from the varying influences of the state, industry associations, corporations and other stakeholders-is useful [50]. In the context of a review, Clarke and Bennett Moses [50] found only a small number of initiatives in all three areas. However, with regard to the growing UAV industry and the resulting competition, it is expected that efforts towards industrial co-regulations will gain importance. It is likely that key players will play an important role in establishing internationally recognized standards in order to increase entry barriers against new market competitors. Industrial design standards for UAV components or standardized communication devices that prevent mid-air collisions are conceivable examples. Besides the influence of industrial manufacturers, professional users are expected to play another key role in regulating the use of UAVs. Their involvement will probably contribute to the decision as to whether UAVs are going to be a tool for everyone or just for professionals. According to the market interests of professional UAV users, their vote is likely to be for the benefit of already established UAV professionals and conventional image suppliers who extended their business by taking stakes in UAV companies.

As already discussed earlier, public acceptance is one cornerstone for the integration of UAVs into society. Here, public awareness and familiarity with the UAV technology but also evident societal benefits will probably push acceptability. Current media coverage is mostly very polarized which consequently shapes citizens' sentiments towards both extremes: positive and negative. However, existing resentments can be neutralized by educational processes, awareness campaigns and through easily accessible and authoritative information. Furthermore, it is important to highlight the nature of public acceptance: this mainly refers to acceptance of the associated risks rather than to acceptance to the technology itself [100]. Within a study on UAV credibility with the public, pointed out that the public shows a tendency to "overestimate small risks and to underestimate large risks" [100]. Thus, information about best practices and the awareness of potential benefits to the society will increase existing knowledge about UAV technology and help developing objective opinions about associated risks: "[This] will be influential in shaping public perceptions, and ultimately, acceptance of [UAV] technologies" [106]. 
In essence, besides using law as a tool to manage risk, Ison, R. et al. [107] identified market mechanisms and information provision to be further ways of controlling to control behaviour. Although that particular framework was published in the context of the sustainable management and use of water, parallels to the question of how to regulate UAVS can be drawn. Past, present and future trends, as outlined in the results and discussion section can be linked with developments in the law, the market, or information (Figure 6). Currently, legal frameworks are the driving force that regulate the use of UAVs. However, due to the growing UAV market, it is highly likely that the market mechanism will soon gain most importance. Furthermore, information and education as enabling tools for public acceptance and a wide integration of UAVs into society are expected to receive increasing attention. However, without the basic requirement of political will, changes are unlikely to happen. Although UAV regulations are in place in about one-third (65) of all countries, gaps and lack of capacity can be seen when it comes to both enforcement and implementation.

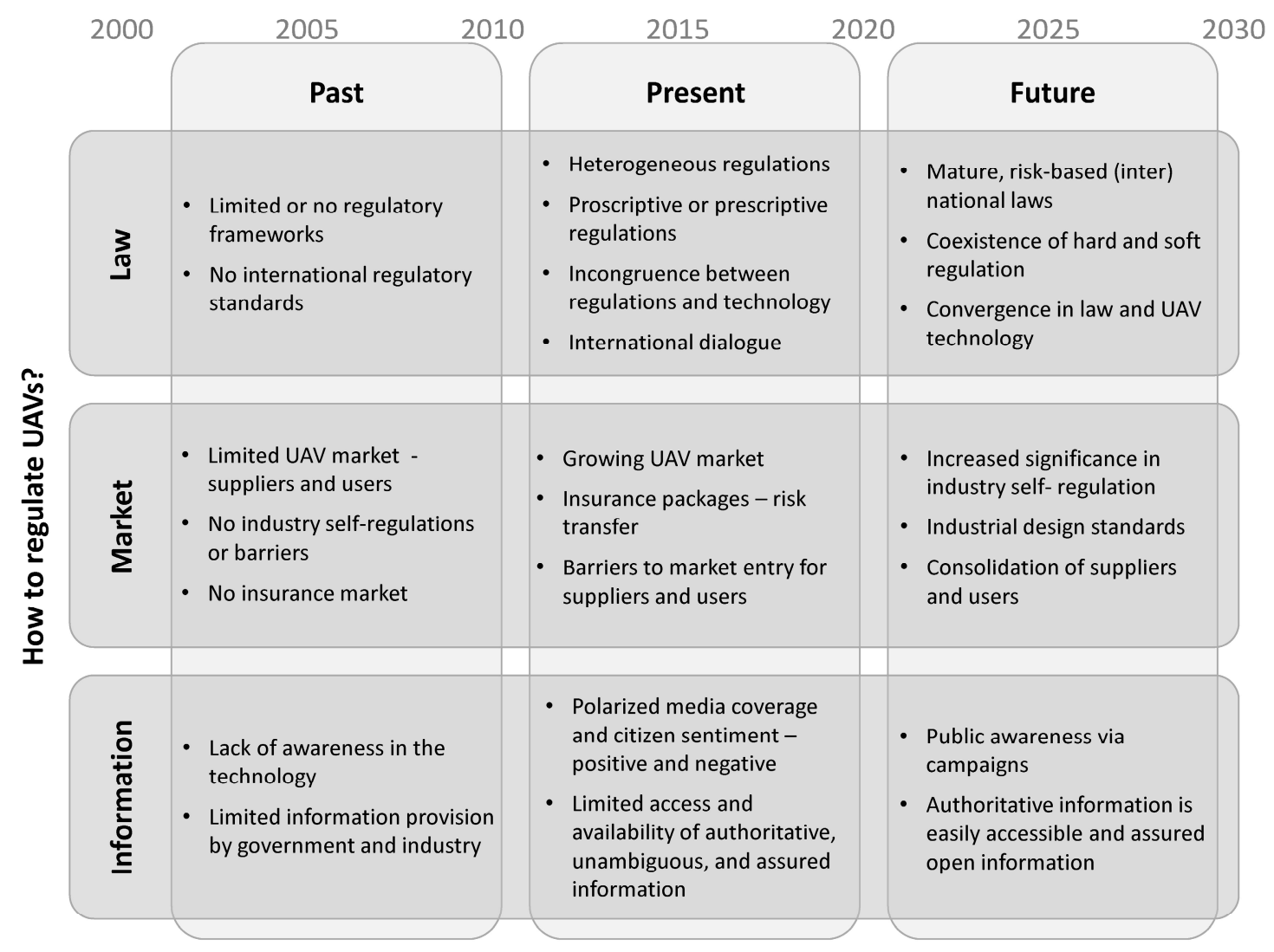

Figure 6. Consolidated overview of past, present and future developments distinguished according to main regulatory mechanism law, market and information.

\subsection{Limitations of This Research}

In terms of the extent of this research, the number of variables was limited to the insights that could be gained by reviewing national regulatory frameworks that deal with UAVs. However, additional criteria, such as political will, establishment of dedicated institutional units, rulemaking parties, and social acceptance, could also be valuable sources of information, but would demand other research methods that were not within the scope of this article. Although enacted UAV regulations are expressed in the form of tangible documents, they do not allow insights "behind the scenes" such as political backgrounds, law enforcement, human capacities and processes. Thus, the presence of UAV regulations does not necessarily mean that UAV operations will be straightforward. 


\section{Conclusions}

This research investigation is the first to provide a holistic global overview of the current status of unmanned aerial vehicle (UAV) regulations. It further delivers insights into the past, present and future development of legal frameworks that regulate the use of UAVs. Based on a research synthesis that includes a thorough literature review and comparative analysis of 19 national regulatory frameworks, similarities and contrasting elements in various national UAV regulations and their implications for data acquisition activities are explored. In essence, regulations target the management of risks and minimization of perceived harms. Within the context of UAVs, the main harms are malfunction, mid-air collisions and consequent damages to people and property on the ground. To address these harms, it is found that UAV regulations focus upon three key aspects: (1) targeting the regulated use of airspace by UAVs; (2) imposing operational limitations; and (3) tackling the administrative procedures of flight permissions, pilot licenses and data collection authorization. Since the early 2000s, countries have gradually established national legal frameworks for UAVs. Although all UAV regulations aim at one common goal-minimizing the risks for other airspace users and for both people and property on the ground-a distinct heterogeneity of national regulations exists. However, commonalities such as mandatory platform registration, obligatory insurance coverage and standard pilot licensing procedures indicate trends towards mature national UAV regulation. Desirable trends are seen in the coexistence of hard and soft regulations, and in the successful international dialogue which will eventually provide a legal framework for harmonized regulatory standards. Besides the strong presence of law, market forces such as industry design standards and reliable information are public goods that are expected to shape future developments.

One direction for further research is related to the implementation of UAV regulations. Although this review article focuses mainly on the content of respective regulatory frameworks, it can only provide limited statements regarding internal administrative processes, local capacities and subsequent implications for the dissemination of UAV technology. Another direction for further research entails a detailed investigation of the impact of the release of UAV regulations on realized UAV flights and economic developments in UAV businesses.

Acknowledgments: The research described in this paper was funded by the research project "its4land," which is part of the Horizon 2020 program of the European Union, project number 687828.

Author Contributions: Claudia Stöcker collected and analyzed the data for this review. All authors contributed to the interpretation of the data. Additionally, they supervised the process of defining the structure and relevant content of this paper. The manuscript was written by Claudia Stöcker with contributions from Rohan Bennett, Francesco Nex, Markus Gerke, and Jaap Zevenbergen.

Conflicts of Interest: The authors declare no conflict of interest.

\section{References}

1. International Civil Aviation Organization (ICAO). Unmanned Aircraft Systems (UAS); ICAO: Montreal, QC, Canada, 2011.

2. Zhou, G.; Ambrosia, V.; Gasiewski, A.J.; Bland, G. Unmanned airborne vehicle (UAV) sensing systems for earth observations. IEEE Trans. Geosci. Remote Sens. 2009, 47, 687-689. [CrossRef]

3. Nex, F.; Remondino, F. UAV for 3D mapping applications: A review. Appl. Geomat. 2014, 6, 1-15. [CrossRef]

4. Colomina, I.; Molina, P. Unmanned aerial systems for photogrammetry and remote sensing: A review. ISPRS J. Photogramm. Remote Sens. 2014, 92, 79-97. [CrossRef]

5. Eisenbeiß, H. UAV Photogrammetry; ETH: Zurich, Switzerland, 2009.

6. Watts, A.C.; Ambrosia, V.G.; Hinkley, E.A. Unmanned aircraft systems in remote sensing and scientific research: Classification and considerations of use. Remote Sens. 2012, 4, 1671-1692. [CrossRef]

7. Anders, N.; Masselink, R.; Keesstra, S.; Suomalainen, J. High-Res Digital Surface Modeling using Fixed-Wing UAV-based Photogrammetry. In Proceedings of the Geomorphometry 2013, Nanjing, China, 16-20 October 2013; pp. 2-5. 
8. D'Oleire-Oltmanns, S.; Marzolff, I.; Peter, K.D.; Ries, J.B. Unmanned aerial vehicle (UAV) for monitoring soil erosion in Morocco. Remote Sens. 2012, 4, 3390-3416. [CrossRef]

9. Stöcker, C.; Eltner, A.; Karrasch, P. Measuring gullies by synergetic application of UAV and close range photogrammetry-A case study from Andalusia, Spain. Catena 2015, 132, 1-11. [CrossRef]

10. Harwin, S.; Lucieer, A. Assessing the accuracy of georeferenced point clouds produced via multi-view stereopsis from unmanned aerial vehicle (UAV) imagery. Remote Sens. 2012, 4, 1573-1599. [CrossRef]

11. Remondino, F. Heritage recording and 3D modeling with photogrammetry and 3D scanning. Remote Sens. 2011, 3, 1104-1138. [CrossRef]

12. Grenzdörffer, G.; Engel, A.; Teichert, B. The photogrammetric potential of low-cost UAVs in forestry and agriculture. In Proceedings of the International Archives of the Photogrammetry, Remote Sensing and Spatial Information Science, Beijing, China, 3-11 July 2008; Volume 1, pp. 1207-1213.

13. Zhang, C.; Kovacs, J.M. The application of small unmanned aerial systems for precision agriculture: A review. Precis. Agric. 2012, 13, 693-712. [CrossRef]

14. Honkavaara, E.; Kaivosoja, J.; Mäkynen, J.; Pellikka, I.; Pesonen, L.; Saari, H.; Salo, H.; Hakala, T.; Marklelin, L.; Rosnell, T. Hyperspectral reflectance signatures and point clouds for precision Agriculture by light weight UAV imaging system. ISPRS Ann. Photogramm. Remote Sens. Spat. Inf. Sci. 2012, 1-7, 353-358. [CrossRef]

15. Hunt, E.R.; Dean Hively, W.; Fujikawa, S.J.; Linden, D.S.; Daughtry, C.S.T.; McCarty, G.W. Acquisition of NIR-green-blue digital photographs from unmanned aircraft for crop monitoring. Remote Sens. 2010, 2, 290-305. [CrossRef]

16. Berni, J.; Zarco-Tejada, P.J.; Suarez, L.; Fereres, E. Thermal and narrowband multispectral remote sensing for vegetation monitoring from an unmanned aerial vehicle. IEEE Trans. Geosci. Remote Sens. 2009, 47, 722-738. [CrossRef]

17. Adams, S.M.; Friedland, C.J. A Survey of Unmanned Aerial Vehicle (UAV) Usage for Imagery Collection in Disaster Research and Management. In Proceedings of the 9th International Workshop on Remote Sensing for Disaster Response, Stanford, CA, USA, 15-16 September 2011.

18. Maza, I.; Caballero, F.; Capitán, J.; Martínez-De-Dios, J.R.; Ollero, A. Experimental results in multi-UAV coordination for disaster management and civil security applications. J. Intell. Robot. Syst. Theory Appl. 2011, 61, 563-585. [CrossRef]

19. Doherty, P.; Rudol, P. A UAV search and rescue scenario with human body detection and geolocalization. In Proceedings of the AI 2007-Australasian Joint Conference on Artificial Intelligence, Gold Coast, Australia, 2-6 December 2007; pp. 1-13.

20. Siebert, S.; Teizer, J. Mobile 3D mapping for surveying earthwork projects using an unmanned aerial vehicle (UAV) system. Autom. Constr. 2014, 41,1-14. [CrossRef]

21. Gevaert, C.; Sliuzas, R.; Persello, C.; Vosselman, G. Opportunities for UAV mapping to support unplanned settlement upgrading. In Proceedings of the GeoTech Rwanda 2015, Kigali, Rwanda, 18-20 November 2015.

22. Aicardi, I.; Nex, F.; Gerke, M.; Lingua, A. An image-based approach for the co-registration of multi-temporal UAV image datasets. Remote Sens. 2016, 8, 779. [CrossRef]

23. Remondino, F.; Barazzetti, L.; Nex, F.; Scaioni, M.; Sarazzi, D. UAV Photogrammetry for Mapping and 3D Modeling-Current Status and Future Perspectives. Int. Arch. Photogramm. Remote Sens. Spat. Inf. Sci. 2011, XXXVIII, 14-16. [CrossRef]

24. Agüera-Vega, F.; Carvajal-Ramírez, F.; Martínez-Carricondo, P. Assessment of photogrammetric mapping accuracy based on variation ground control points number using unmanned aerial vehicle. Measurement 2017, 98, 221-227. [CrossRef]

25. Agüera-Vega, F.; Carvajal-Ramírez, F.; Martínez-Carricondo, P. Accuracy of digital surface models and orthophotos derived from unmanned aerial vehicle photogrammetry. J. Surv. Eng. 2016, 143, 4016025. [CrossRef]

26. Barnes, G.; Volkmann, W. High-resolution mapping with unmanned aerial systems. Surv. Land Inf. Sci. 2015, 74, 5-13.

27. Meha, M.; Kelm, K.; Çaka1, M.; Sinani1, Q.; Ahmetaj, K. UAV technology and open source software for systematic registration in the Republic of Kosovo. In Proceedings of the Land and Poverty Conference 2016: Scaling up Responsible Land Governance, Washington, DC, USA, 14-18 March 2016. 
28. Crommelinck, S.; Bennett, R.; Gerke, M.; Nex, F.; Yang, M.Y.; Vosselman, G. Review of automatic feature extraction from high-resolution optical sensor data for UAV-based cadastral mapping. Remote Sens. 2016, 8, 689. [CrossRef]

29. Mumbone, M.; Bennett, R.M.; Gerke, M.; Volkmann, W. Innovations in boundary mapping: Namibia, customary lands and UAVs. In Proceedings of the Land and Poverty Conference 2015: Linking Land Tenure and Use for Shared Prosperity, Washington, DC, USA, 23-27 March 2015.

30. Koh, L.P.; Wich, S.A. Dawn of drone ecology: Low-cost autonomous aerial vehicles for conservation. Trop. Conserv. Sci. 2012, 5, 121-132. [CrossRef]

31. Jain, M. A next-generation approach to the characterization of a non-model plant transcriptome. Curr. Sci. 2011, 101, 1435-1439.

32. Pajares, G. Overview and current status of remote sensing applications based on unmanned aerial vehicles (UAVs). Photogramm. Eng. Remote Sens. 2015, 81, 281-330. [CrossRef]

33. Everaerts, J. The use of unmanned aerial vehicles (UAVs) for remote sensing and mapping. Int. Arch. Photogramm. Remote Sens. Spat. Inf. Sci. 2008, XXXVII, 1187-1192.

34. Carvajal-Ramírez, F.; Agüera-Vega, F.; Martínez-Carricondo, P.J. Effects of image orientation and ground control points distribution on unmanned aerial vehicle photogrammetry projects on a road cut slope. J. Appl. Remote Sens. 2016, 10, 34004. [CrossRef]

35. Zein, T. Fit-For-Purpose Land Administration: An implementation model for cadastre and land administration systems. In Proceedings of the Land and Poverty Conference 2016: Scaling up Responsible Land Governance, Washington, DC, USA, 14-18 March 2016.

36. Haarbrink, R.B. Uas for Geo-Information: Current Status and Perspectives. Int. Arch. Photogramm. Remote Sens. Spat. Inf. Sci. 2012, XXXVIII-1, 207-212.

37. Finn, R.L.; Wright, D. Study on Privacy, Data Protection and Ethical Risks in Civil Remotely Piloted Aircraft Systems Operations Final Report; European Comission: Brussels, Belgium, 2014.

38. Van Blyenburgh, P. Harmonising UAS Regulations and Standards; UAS Special Issue; GIM International: Lemmer, The Netherlands, 2016.

39. Van Wegen, W.; Stumpf, J. Bringing a New Level of Intelligence to UAVs_Interview with Jan Stumpf; UAS Special Issue; GIM International: Lemmer, The Netherlands, 2016.

40. Boucher, P. Domesticating the drone: The demilitarisation of unmanned aircraft for civil markets. Sci. Eng. Ethics 2015, 21, 1393-1412. [CrossRef] [PubMed]

41. Rango, A.; Laliberte, A.S. Impact of flight regulations on effective use of unmanned aircraft systems for natural resources applications. J. Appl. Remote Sens. 2010, 4, 043539.

42. International Civil Aviation Organization (ICAO). Manual on Remotely Piloted Aircraft Systems (RPAS); ICAO: Montréal, QC, Canada, 2015.

43. Morales, A.C.; Paez, D.; Arango, C. Multi-criteria analysis of UAVs regulations in 6 countries using the analytical hierarchical process and expert knowledge. In International Conference on Unmanned Aerial Vehicles in Geomatics; ISPRS: Toronto, ON, Canada, 2015; Volume 40, pp. 175-181.

44. Villasenor, J. Observations from above: Unmanned aircraft systems and privacy. Harv. J. Law Public Policy 2013, 36, 457.

45. Jansen, P. The Ethics of Domestic Drones-An Evaluation of the Use of Surveillance-Capable Unmanned Aerial Systems in Civil Contexts. Master's Thesis, University of Twente, Enschede, The Netherlands, 2015.

46. Finn, R.L.; Wright, D. Unmanned aircraft systems: Surveillance, ethics and privacy in civil applications. Comput. Law Secur. Rev. 2012, 28, 184-194. [CrossRef]

47. Finn, R.L.; Wright, D. Privacy, data protection and ethics for civil drone practice: A survey of industry, regulators and civil society organisations. Comput. Law Secur. Rev. 2016, 32, 577-586. [CrossRef]

48. European RPAS Steering Group. Roadmap for the Integration of Civil Remotely-Piloted Aircraft Systems into the European Aviation System. Available online: http:/ /ec.europa.eu/DocsRoom/documents/10484/ attachments/1/translations/en/renditions/native (accessed on 13 October 2016).

49. EU Responsible Research and Innovation (RRI). Available online: http://ec.europa.eu/programmes/ horizon2020/en/h2020-section/responsible-research-innovation (accessed on 31 October 2016).

50. Clarke, R.; Bennett Moses, L. The regulation of civilian drones' impacts on behavioural privacy. Comput. Law Secur. Rev. 2014, 30, 286-305. [CrossRef] 
51. Bennett Moses, L. Recurring Dilemmas: The Laws's Race to Keep Up with Technological Change. J. Law Technol. Policy 2007, 2, 239-285. [CrossRef]

52. Cooper, H.; Hedges, L.V. Research synthesis as a scientific process. In The Handbook of Research Synthesis and Meta-Analysis, 2nd ed.; Russell Sage Foundation: New York, NY, USA, 2009; pp. 3-17.

53. Bennett Moses, L. How to Think about Law, Regulation and Technology: Problems with "Technology" as a Regulatory Target. Law Innov. Technol. 2013, 1, 1-20. [CrossRef]

54. EUROCONTROL List of UAV Regulations. Available online: http://www.eurocontrol.int/articles/nationalrpas-regulations (accessed on 15 October 2016).

55. JARUS List of UAV Regulations. Available online: http://jarus-rpas.org/regulations (accessed on 15 October 2016).

56. Global Drone Regulations Database. Available online: https://droneregulations.info/index.html (accessed on 15 October 2016).

57. UVS International Regulation Monitor Europe. Available online: http://uvs-info.com/index.php/europeanmatters/regulation-monitor-europe/european-matters-regulation-monitor-europe-open-access (accessed on 15 October 2016).

58. EU Drone Regulation. Available online: http://dronerules.eu/en/professional/regulations (accessed on 15 October 2016).

59. Lijphart, A. Comparative Politics and the Comparative Method. Am. Polit. Sci. Rev. 1971, 65, 682-693. [CrossRef]

60. UNC Comparing and Contrasting. Available online: http://writingcenter.unc.edu/handouts/comparingand-contrasting/ (accessed on 10 October 2016).

61. Kumar, R. Research Methodology; SAGE: New York, NY, USA, 2014.

62. International Civil Aviation Organization (ICAO). Convention on International Civil Aviation; ICAO: Chicago, IL, USA, 1944.

63. The Japan Times. Man Who Landed Drone on Roof of Japanese Prime Minister's Office Gets Suspended Sentence. Available online: http://www.japantimes.co.jp/news/2016/02/16/national/crime-legal/manlanded-drone-roof-japanese-prime-ministers-office-gets-suspended-sentence/\#.WFEvqIrQf_w (accessed on 17 December 2016).

64. Joint Aviation Authorities; Eurocontrol. A Concept for European Regulations for Civil Umanned Aerial Vehicles (UAVs); UAV TASK-FORCE Final Report; 2004. Available online: http:/ /www.easa.europa.eu/ system/files/dfu/NPA_16_2005_Appendix.pdf (accessed on 15 October 2016).

65. Joint Authorities for Rulemaking of Unmanned Systems (JARUS). Certification Specification for Light Unmanned Rotorcraft Systems (CS-LURS); 2013. Available online: http:/ /www.nlr.nl/downloads/jarus_cslurs.pdf (accessed on 15 Octboer 2016).

66. Joint Authorities for Rulemaking of Unmanned Systems. JARUS RPAS "Required C2 Performance" (RLP) Concept; 2016. Available online: https://jarus-rpas.org/sites/jarus-rpas.org/files/storage/LibraryDocuments/jar_doc_13_rpl_concept_upgraded.pdf (accessed on 15 Octboer 2016).

67. Joint Authorities for Rulemaking of Unmanned Systems. JARUS FCL Recommendation; 2015. Available online: http://jarus-rpas.org/sites/jarus-rpas.org/files/jar_03_doc-fcl_0.pdf (accessed on 15 Octboer 2016).

68. European Aviation Safety Agency (EASA). Riga Declaration on Remotely Piloted Aircraft (Drones); EASA: Riga, Latvia, 2015.

69. European Aviation Safety Agency (EASA). A Proposal to Create Common Rules For operating Drones in Europe; EASA: Cologne, Germany, 2015.

70. European Aviation Safety Agency (EASA). "Prototype" Commission Regulation on Unmanned Aircraft Operations-Explanatory Note; EASA: Cologne, Germany, 2016; Volume 149.

71. European Aviation Safety Agency (EASA). Concept of Operations for Drones: A Risk Based Approach to Regulation of unmanned Aircraft; EASA: Cologne, Germany, 2015.

72. UAViators. Humanitarian UAV Network. UAV Code of Conduct \& Guidelines; 2015. Available online: http:/ / uaviators.org/docs (accessed on 15 October 2016).

73. Civil Aviation Authority UK. Unmanned Aircraft System Operations in UK Airspace-Guidance; 2015. Available online: https://publicapps.caa.co.uk/docs/33/CAP\%20722\%20Sixth\%20Edition\%20March\% 202015.pdf (accessed on 15 October 2016). 
74. CASA Advisory Cirular. AC 101-10 Remotely Piloted Aircraft Systems-Operation of Excluded RPA (Other than Model Aircraft); 2016. Available online: https://www.casa.gov.au/files/ac10110pdf (accessed on 15 February 2017).

75. Aeronautical Information Services Malaysia. Unmanned Aerial Vehicle (UAV) Operations in Malaysian Airspace; 2008. Available online: http://aip.dca.gov.my/aip\%20pdf\%20new/AIC/AIC\%20200804.pdf (accessed on 15 February 2017).

76. U.S. Department of Transportation Federal Aviation Administration. Advisory Circular Small Unmanned Aircraft Systems (sUAS); 2016. Available online: https://www.faa.gov/regulations_policies/advisory_ circulars/index.cfm/go/document.list/parentTopicID/137 (accessed on 15 October 2016).

77. Transport Canada. Notice of Proposed Amendment Unmanned Air Vehicles; 2015. Available online: http:/ / wwwapps.tc.gc.ca/Saf-Sec-Sur/2/NPA-APM/doc.aspx?id=10294 (accessed on 15 February 2017).

78. Diretion Generale de l'Aviation Civile Guide DSAC-Aeronefs Circulant Sans Personne a Bord: Activites Particulieres; 2016. Available online: http://www.developpement-durable.gouv.fr/sites/default/files / Guide\%20Activités\%20particulières\%20v1.2\%2010jan17.pdf (accessed on 15 February 2017).

79. ILT Staatscourant Nr. 27761; 2016. Available online: https://www.ilent.nl/onderwerpen/transport/ luchtvaart/dronevliegers/ (accessed on 15 February 2017).

80. Deutsche Flugsicherung. Nachrichten fuer Luftfahrer; 2016. Available online: https://www.dfs.de/dfs_ homepage/de/Unternehmen/Richtlinien/1-786-16.pdf (accessed on 15 February 2017).

81. L'Ente Nazionale per l'Aviazione Civile. Regulation Remotely Piloted Aerial Vehicles; 2015. Available online: https:/ / www.enac.gov.it/La_Normativa/Normativa_Enac/Regolamenti/Regolamenti_ad_hoc/ info-122671512.html (accessed on 15 February 2017).

82. Austro Control Lufttüchtigkeits- und Betriebstüchtigkeitsanforderungen für Unbemannte Luftfahrzeuge der Klasse 1; 2015. Available online: http://www.ris.bka.gv.at/Dokument.wxe?Abfrage=Bundesnormen\& Dokumentnummer=NOR40151655 (accessed on 15 February 2017).

83. Ministerio De Agricultura. Boletín oficial del estado Aeronaves civiles pilotadas por control remoto; 2014. Available online: http:/ /www.boe.es/boe/dias/2014/10/17/pdfs/BOE-A-2014-10517.pdf (accessed on 18 March 2017).

84. Republic of Azerbaijan State Civil Aviation Administration. Unmanned Aircraft Operations; 2015. Available online: http://www.caa.gov.az/index.php?option=com_k2\&view=item\&id=297:unmannedaircraft-operations\&Itemid=174\&lang=en (accessed on 15 February 2017).

85. Direccion General De Aeronautica Chile Dan 151-Operaciones de Aeronaves Pilotadas a Distancia (RPAS). Available online: https://www.dgac.gob.cl/portalweb/rest-portalweb/jcr/repository/collaboration/ sites\%20content/live/dgac/categories/normativas/normasDAN/documents/DAN_151-20150413.pdf (accessed on 15 February 2017).

86. Aeronautica Civil de Colombia Requisitos Generales de Aeronavegabilidad y Operaciones para RPAS; 2015. Available online: http://www.aerocivil.gov.co/autoridad-de-la-aviacion-civil/certificacion-ylicenciamiento/Documents/CIRCULAR\%20REGLAMENTARIA \%20\%20002\%20-\%20RPAS.pdf\#search= RPAS (accessed on 15 February 2017).

87. South African Civil Aviation Authority Technical Guidance Material for RPAS Part 101. Available online: http://www.caa.co.za/Pages/RPAS/Remotely\%20Piloted\%20Aircraft\%20Systems.aspx (accessed on 28 March 2017).

88. Japan Ministry of Land Infrastructure Transport and Tourism Amendments to the Aeronautical Act. Available online: http:/ / www.mlit.go.jp/en/koku/uas.html (accessed on 15 February 2017).

89. Federal Republic of Nigeria. Nigeria Civil Aviation Regulation. Available online: http://ncaa.gov.ng/ncaaissues-safety-guidelines-for-drone-operators / (accessed on 15 February 2017).

90. Rwanda Civil Aviation Authority Ministerial Regulations No. 01/MOS/Trans/016 of 26/04/2016 Relating to Unmanned Civil Aircraft System. Available online: https://www.caa.gov.rw/fileadmin/templates/ Regulatory_Services/Ministerial_Regulations_N__01-MOS-Trans-016_OF_26-04-2016_relating_to_ Unmanned_Civil_Aircraft_Systems_UAS_.PDF (accessed on 15 February 2017).

91. Civil Aviation Administration of China Measures for the Administration of Air Traffic in Civil Unmanned Aircraft Systems. Available online: http:/ / www.caac.gov.cn/XXGK/XXGK/GFXWJ/201610/ P020161008345668760913.pdf (accessed on 15 February 2017). 
92. Yu, X.; Zhang, Y. Sense and avoid technologies with applications to unmanned aircraft systems: Review and prospects. Prog. Aerosp. Sci. 2015, 74, 152-166. [CrossRef]

93. Federal Aviation Administration. Operation and Certification of Small Unmanned Aircraft Systems. 2016. Available online: https:/ / federalregister.gov/a/2016-15079 (accessed on 15 February 2017).

94. Federal Aviation Administration B4UFLY. Available online: https://www.faa.gov/uas/where_to_fly/ b4ufly/ (accessed on 12 December 2016).

95. Civil Aviation Authority UK Drone Aware. Available online: http://droneaware.org (accessed on 12 December 2016).

96. Veilig Fliegen. Available online: http://www.veiligvliegen.nl (accessed on 12 December 2016).

97. Clothier, R.A.; Palmer, J.L.; Walker, R.A.; Fulton, N.L. Definition of an airworthiness certification framework for civil unmanned aircraft systems. Saf. Sci. 2011, 49, 871-885. [CrossRef]

98. Rao, B.; Gopi, A.G.; Maione, R. The societal impact of commercial drones. Technol. Soc. 2016, 45, 83-90. [CrossRef]

99. Clothier, R.; Fulton, N.; Walker, R. Pilotless aircraft: The horseless carriage of the twenty-first century? J. Risk Res. 2008, 11, 999-1023. [CrossRef]

100. European RPAS Steering Group Roadmap for the Integration of Civil Remotely—Piloted Aircraft Systems into the European Aviation System-ANNEX 3; 2013. Available online: http:/ / ec.europa.eu/growth/sectors/ aeronautics/rpas_en (accessed on 15 January 2017).

101. Space53 Nokia Smart-City-Traffic-Management. Available online: www.space53.nl/2016/09/25/nokia-andeuropes-first-drone-based-smart-city-traffic-management-test-facility-collaborate-to-ensure-safe-globalaerial-operations/ (accessed on 27 January 2017).

102. Marzocchi, O. Privacy and Data Protection Implications of the Civil Use of Drones. Brussels, Belgium, 2015. Available online: https:/ / free-group.eu/2015/06/12/privacy-and-data-protection-implications-ofthe-civil-use-of-drones / (accessed on 16 January 2017).

103. Cavoukian, A. Privacy and Drones: Unmanned Aerial Vehicles; Information and Privacy Commissioner of Ontario: Toronto, ON, Canada, 2012.

104. JARUS Certification Specification for Light Unmanned Rotorcraft Systems; 2013. Available online: http://jarus-rpas.org/sites/jarus-rpas.org/files/storage/Library-documents/jar_01_doc_jarus_ certification_specification_for_lurs_-_30_oct_2013.pdf (accessed on 17 October 2016).

105. Marchant, G.E.; Allenby, B.R.; Herkert, J.R. The Growing Gap between Emerging Technologies and Legal-Ethical Oversight: The Pacing Problem, 7th ed.; Springer: New York, USA, 2011; Available online: http: //www.worldcat.org/title/privacy-and-drones-unmanned-aerial-vehicles/oclc/818083884 (accessed on 15 January 2017).

106. Clothier, R.A.; Greer, D.A.; Greer, D.G.; Mehta, A.M. Risk Perception and the Public Acceptance of Drones. Risk Anal. 2015, 35, 1167-1183. [CrossRef] [PubMed]

107. Ison, R.; Röling, N.; Watson, D. Challenges to science and society in the sustainable management and use of water: investigating the role of social learning. Environ. Sci. Policy 2007, 10, 499-511. [CrossRef]

(c) 2017 by the authors. Licensee MDPI, Basel, Switzerland. This article is an open access article distributed under the terms and conditions of the Creative Commons Attribution (CC BY) license (http://creativecommons.org/licenses/by/4.0/). 